\title{
Św. Jan Chryzostom, O Dawidzie i Saulu. Homilia pierwsza (CPG 4412: De Davide et Saule. Homilia prima) ${ }^{1}$
}

\section{Wstęp}

Przystępując do lektury pierwszej homilii Jana Chryzostoma z jego cyklu De Davide et Saule, czytelnik winien otrzymać, po pierwsze, garść danych zarówno o Złotoustym, największym, jak bywa on nazywany, kaznodziei Kościoła wschodniego, jak i o całym korpusie jego dzieł oraz, po wtóre, nieco więcej może i bardziej szczegółowych informacji o odnośnym już jego kazaniu. Wiadomości jednego i drugiego rodzaju pomieszczone zostały w niniejszym wstępie.

\section{Zarys biografii Jana Chryzostoma i krótki przegląd korpusu jego dziel}

$\mathrm{Jan}^{2}$ urodził się około 350 roku w Antiochii, a więc w Syrii, w arystokratycznej rodzinie chrześcijańskiej, zmarł natomiast, idąc na wygnanie,

1 Niniejsze tłumaczenie wraz z poprzedzającym je wstępem i uzupełniającymi komentarzami stanowiło następującą pracę licencjacką, obronioną 29 czerwca 2020 roku na Wydziale Nauk Humanistycznych Katolickiego Uniwersytetu Lubelskiego Jana Pawła II w ramach kierunku filologia klasyczna: Łukasz Libowski, Jana Chryzostoma pierwsza homilia do historii o Dawidzie i Saulu - wstęp, przekład, komentarz, Lublin 2020. Promotorem pracy była dr hab. Ewa Osek, prof. KUL, zrecenzował ją natomiast dr hab. Krzysztof Narecki, prof. KUL. Należy w tym miejscu złożyć najserdeczniejsze podziękowanie zarówno recenzentowi, Panu Profesorowi Krzysztofowi Nareckiemu, jak i - przede wszystkim - promotorowi, Pani Profesor Ewie Osek, że w sposób wydatny przyczynili się do tego, iż publikowany materiał przybrał ostatecznie taki kształt, jaki przybrał.

2 Przedstawiając życie Chryzostoma, opieram się tu zasadniczo na następującym opracowaniu: F. Drączkowski, Jan Chryzostom, w: Encyklopedia katolicka, t. 7, red. S. Wielgus, Lublin 1997, s. 766-769. Zob. także podaną tam dalszą literaturę. Gdy chodzi o bibliografię, to warto skorzystać z doskonałego opracowania dostępnego w serwisie Academia.edu (www.academia.edu), obejmującego publikacje poświęcone Janowi 
14 września 407 roku w Comana Pontica, mieście, jak to oznajmia jego nazwa, leżącym w Poncie. Ponieważ wcześnie stracił ojca, był wychowywany przez matkę. Filozofii uczył się u Androgotusa, retoryki zaś u wielkiego Libaniusza, przedstawiciela platońskiej szkoły pergamońskiej, autora zaliczanego do drugiej sofistyki, co ciekawe, zagorzałego przeciwnika wiary i religii chrześcijańskiej, który w Janie widział swego następcę. W roku 369 Jan przyjął chrzest i pod kierownictwem Diodora $z$ Tarsu oddał się studiom biblijnym. W latach 371-377 prowadził życie pustelnicze: najpierw, do roku 375, pod przewodnictwem doświadczonego eremity, później natomiast $\mathrm{w}$ całkowitym odosobnieniu. W tym czasie uczył się na pamięć całego Pisma Świętego. Kiedy od nadmiernych umartwień ascetycznych podupadł na zdrowiu, powrócił do Antiochii.

Tu w 381 roku z rąk patriarchy Melecjusza przyjął święcenia diakonatu, a sześć lat później, w 386 roku, przez patriarchę Flawiana I został wyświęcony na prezbitera. Jako kapłan spędził w swoim rodzinnym mieście dwanaście lat, w głównych tutejszych kościołach głosząc Słowo Boże. W tym właśnie okresie swego życia zyskał sławę wybitnego kaznodziei i to wówczas nadano mu przydomek ,Złotousty”.

W 397 roku na mocy postanowienia cesarza Arkadiusza został Jan zaznaczmy, iż wbrew swojej woli - patriarchą Konstantynopola. Na biskupa konsekrował go 28 lutego 398 roku biskup Teofil z Aleksandrii. Gorliwie duszpasterzował Chryzostom w Kościele konstantynopolitańskim: zreformował i odnowił życie tamtejszej wspólnoty. Wymieńmy tu dla przykładu jedynie - następujące, co ważniejsze jego dokonania: likwidacja przepychu rezydencji biskupiej, usunięcie z urzędów kilku biskupów symoniackich, zobowiązanie mnichów do ascezy i do stałego przebywania w klasztorach, walka ze zbytkiem bogaczy, zakładanie hospicjów i szpitali, zorganizowanie opieki duszpasterskiej dla Gotów przebywających w stolicy, troska o misje w Tracji i Fenicji, przyjęcie do diecezji mnichów nitryjskich oskarżonych przez swojego biskupa o orygenizm. Był Jan przewodnikiem wspólnoty Kościoła bezkompromisowym i szczerym, które to

Złotoustemu i jego dziełu, które zostały ogłoszone do 2016 roku: Chrysostomica: An Online Bibliography of Scholarship on John Chrysostom and Attributed Writings, opr. W. Mayer, w: https://www.academia.edu/6448870/Chrysostomica_An_Online_ Bibliography_of_Scholarship_on_John_Chrysostom_and_Attributed_Writings (dostęp: 09.06.2020). Potrzeba tu koniecznie odnotować, że jedną z bodaj najbardziej wyczerpujących biografii Złotoustego, a także gruntowne omówienie jego opus przedkłada w swojej znanej książce: J.N.D. Kelly, Złote usta. Jan Chryzostom - asceta, kaznodzieja, biskup, tł. K. Krakowczyk, Warszawa 2001. 
cechy przysporzyły mu wielu wrogów. Jego nieprzyjaciółką był m.in. cesarzowa Eudoksja, której wytykał niesprawiedliwe postępki i zbytkowne życie. Przez tzw. synod pod dębem w sierpniu 403 roku został skazany na wygnanie do Bitynii, jednak wskutek rozruchów w mieście, a także wypadków, jakie miały miejsce w pałacu cesarskim, jeszcze jesienią tego samego roku powrócił do Konstantynopola. Lecz niebawem znów naraził się władcy, krytykował bowiem jako bałwochwalczą praktykę oddawania czci posągowi cesarzowej. W związku z tym zawiązała się przeciwko niemu intryga. Jej efektem było usunięcie Jana przez cesarza Arkadiusza z piastowanego przezeń urzędu. 9 czerwca 404 roku Chryzostom został skazany na banicję do Kukuzy w Armenii, potem zaś, w 407 roku, do Pityontu nad Morzem Czarnym. W drodze do Pityontu umarł.

Ponieważ kazania z serii De Davide et Saule wygłoszone zostały, jak się powszechnie przyjmuje, w 387 roku $^{3}$, to jest w pierwszym roku kapłaństwa Chryzostoma, a także w roku, w którym wybuchł w Antiochii bunt przeciwko cesarzowi, przyjrzyjmy się pokrótce wydarzeniom z pierwszych miesięcy tegoż roku, wydarzeniom, jakie rozegrały się w rzeczonej metropolii w ramach wspomnianego buntu od 25 lutego do 25 kwietnia ${ }^{4}$. Wiedza o tych wypadkach będzie potrzebna za chwilę dla lepszego zorientowania się w toczącej się w literaturze dyskusji na temat szczegółowej datacji mów Chryzostomowych z cyklu O Dawidzie i Saulu.

Otóż po klęsce pod Adrianopolem - ta miała miejsce 9 sierpnia 378 roku - cesarz Teodozjusz, odbudowując garnizony wschodnie, rozporządził, że w kilku miastach na Wschodzie, w tym w Antiochii, zostanie jeszcze raz zebrany podatek. W mieście Złotoustego dekret cesarski odczytano 25 albo 26 lutego 387 roku, na kilka dni przed rozpoczęciem Wielkiego Postu. Nieszczęsna wiadomość szybko rozeszła się po metropolii, wskutek czego Antiochia rozgorzała. Nim zdołano opanować szalejący tłum, ten zniszczył

\footnotetext{
3 Na temat datacji cyklu De Davide et Saule, zob. punkt 3.1 niniejszego wstępu.

4 Relacjonując te wydarzenia, idę za opracowaniem następującym: J. Iluk, Wstęp, w: Św. Jan Chryzostom, Mowy do Antiocheńczyków o posagach, tł. i kom. J. Iluk, Gdańsk 2017, s. VII-X. Na ten temat zob. także m.in. P. Filipczak, Bunty i niepokoje $w$ miastach wczesnego Bizancjum (IV wiek n.e.), Łódź 2009, s. 81-100; P. Szczur, Rewolta podatkowa w Antiochii (387) w świetle przekazów Jana Chryzostoma i Libaniusza. Retoryka i fakty historyczne, „Roczniki Historii Kościoła” 61 (2009) s. 49-75; R. Browning, The Riot of A.D. 387 in Antioch. The Role of the Theatrical Claques in the Later Empire, ,The Journal of Roman Studies" 42 (1952) s. 13-20; D. French, Rhetoric and Rebellion of A.D. 387 in Antioch, „Historia” 47 (1998) s. 468-484; A.J. Quiroga Puertas, Deflecting Attention an Shaping Reality with Rhetoric: the Case of the Riot of the Statues of A.D. 387 in Antioch, „Nova Tellus” 26 (2008) s. 137-153.
} 
jedną z term. Ponadto - jak pisze Sozomen w swojej Historii Kościoła „zbuntowana [...] ludność Antiochii Syryjskiej poobalała posągi cesarza i jego małżonki, po czym zarzuciwszy na nie pętle wlokła je po ziemi, miotając zelżywe wyzwiska, na jakie oczywiście zdobyć się może wzburzone pospólstwo"s. Ale, jak podaje z kolei Libaniusz, już popołudniem tego samego dnia miasto się uspokoiło ${ }^{6}$. Posłano do cesarza, aby dowiedział się o tym, co zaszło w Antiochii, a miejscowy sąd zaczął wydawać pierwsze wyroki śmierci. Kościół antiocheński znalazł się pomiędzy młotem a kowadłem, to znaczy pomiędzy rozwścieczonym cesarzem Teodozjuszem a zbuntowanym miastem. Kierujący tym Kościołem biskup Flawian wraz ze swoimi kapłanami, przede wszystkim zaś ze świeżo wyświęconym na prezbitera Janem, podjął się mediacji. Pilne były dwie kwestie: trzeba było zarówno udać się do cesarza, jak i opanować lud. Ludem zajął się Złotousty - o tym, jak ,pracował" on wówczas nad antiocheńczykami, wiemy z jego słynnych mów De statuis $^{7}$, do cesarza udał się natomiast Flawian.

Antiocheńczycy spodziewali się najgorszego. Niektórzy z nich ze strachu uciekali ze swoich domów. Po dwóch tygodniach, 15 marca, przybyli do Antiochii urzędnicy cesarscy Ellebich i Cezariusz. I już dwa dni później, 17 marca, rozegrał się wtóry akt antiocheńskiego dramatu. Oto bowiem Ellebich i Cezariusz zakomunikowali antiocheńczykom, jakie są decyzje cesarskie w związku z zaszłymi u nich wypadkami: utrata przez Antiochię godności metropolii, zamknięcie teatru, łaźni i hipodromu, wstrzymanie rozdawnictwa żywności, wyrok śmierci dla niektórych kuriałów oraz bezpośrednich prowodyrów zamieszek. Jednakże niespodziewanie weszli do miasta mnisi z podmiejskich górskich pustelni, którzy zażądali od Ellebicha i Cezariusza, aby wstrzymali wykonanie cesarskich rozporządzeń aż do momentu, kiedy Teodozjusz podejmie w sprawie Antiochii decyzję ostateczną. Cezariusz osobiście udał się więc do Konstantynopola, by zapytać cesarza o jego definitywny werdykt odnośnie do Antiochii. Werdykt ten przychodzi 10 lub 11 kwietnia. Jest następujący: w ramach wielkanocnej abolicji cesarz da-

\footnotetext{
5 Sozomen, Historia Kościoła VII 23, tł. S. Kazikowski, Warszawa 1989, cyt. za: Iluk, Wstęp, s. VIII.

6 Libaniusz, Mowa 22, 9, cyt. za: Iluk, Wstęp, s. IX.

7 Iohannes Chrysostomus, Ad populum Antiochenum homiliae 1-21 (De statuis), PG 49, 15-222, CPG 4330, tł. Św. Jan Chryzostom, Mowy do Antiocheńczyków o posqgach, tł. i kom. J. Iluk, Gdańsk 2017. Najnowszy i najobszerniejszy komentarz do tego zbioru homilii Chryzostomowych stanowi następujące opracowanie: F. van de Poverd, St. John Chrysostom: the Homilies on the Statues, Rome 1991.
} 
ruje antiocheńczykom wszystkie ich winy, ułaskawia kuriałów, a miastu przywraca wszystkie jego przywileje. W Antiochii nastaje zatem wielkie święto. Na kilka zaś dni przed Paschą wraca do domu biskup Flawian, jak relacjonuje Chryzostom, wraz z kopią cesarskiej amnestii uwalniającej wszystkich antiocheńczyków dotąd uwięzionych. Sprawa jest na dobre rozstrzygnięta i zamknięta.

Przechodząc, zgodnie z powziętym planem, do zwięzłego omówienia - właściwie to do przeglądu - spuścizny pisarskiej Chryzostoma, zaznaczmy przede wszystkim i od razu to jedno, iż jest ona ogromna. Był wszak Złotousty najpłodniejszym z greckich ojców Kościoła: wszystkie jego dzieła wypełniają - niemal w całości - osiemnaście tomów Migne'owskich ${ }^{8}$; nota bene zidentyfikowano także mniej więcej dziewięćset pism apokryficznych przypisywanych Chryzostomowi - około trzysta $\mathrm{z}$ nich wydano dotąd drukiem, a sześćset pozostaje w rękopisach. Tę bogatą schedę Janową, o której - jak nadmienia Benedykt XVI - pewien anonimowy kopista zanotował, iż ,przenika [...] całą kulę ziemską, niczym przeszywające niebo błyskawice", zwykło się dzielić na cztery części: na homilie, mowy, traktaty i listy. Powiedzmy słówko o składowych każdej z tych części.

Największy moduł dorobku piśmienniczego Jana Złotoustego to oczywiście - co najbardziej nas tu interesuje - homilie. Badacze wyróżniają w owym zbiorze homilii dwie grupy, mianowicie homilie egzegetyczne do Starego i Nowego Testamentu oraz homilie dogmatyczno-polemiczne. Homilii pierwszego rodzaju jest niezmiernie dużo, to do tej grupy zalicza się zajmujący nas w tym opracowaniu tryptyk De Davide et Saule $e^{10}$, homilii rodzaju drugiego - niewiele. Spośród pierwszych warto wymienić może, oprócz O Dawidzie i Saulu, dwie serie homilii do Ksieggi Rodzaju - seria pierwsza to osiem homilii ${ }^{11}$, a seria druga to homilii sześćdziesiąt siedem ${ }^{12}$

8 PG 47-64.

9 Benedykt XVI, Jan Chryzostom (I). Katecheza z audiencji generalnej z 19 września 2007 r., w: https://opoka.org. pl/biblioteka/W/WP/benedykt_xvi/audiencje/ ag_19092007.html (dostęp: 04.07.2020).

10 Iohannes Chrysostomus, De Davide et Saule homiliae tres, PG 54, 675-708, CPG 4412. Najnowsza edycja krytyczna: Iohannis Chrysostomi De Davide et Saule homiliae tres, ed. F.P. Barone, Corpus Christianorum. Series Graeca 70, Turnhout 2008.

11 Iohannes Chrysostomus, Sermones 1-8 (9) in Genesim, PG 54, 581-630, CPG 4410, t1. Św. Jan Chryzostom, Homilie na Księgę Rodzaju. Seria pierwsza: Rdz 1-3, tł. S. Kaczmarek, Źródła Myśli Teologicznej 45, Kraków 2008.

12 Iohannes Chrysostomus, Homiliae 1-67 in Genesim, PG 53, 21-54, 580, CPG 4409. Po polsku dostępne są fragmenty tych homilii. Zob. W. Stawiszyński, Bibliografia 
- homilie do pięćdziesięciu ośmiu wybranych psalmów ${ }^{13}$, pięć homilii De Anna ${ }^{14}$, o których przyjdzie nam niebawem jeszcze wspomnieć ${ }^{15}$, dziewięćdziesiąt homilii do Ewangelii wedtug świętego Mateusza ${ }^{16}$, osiemdziesiąt osiem homilii do Ewangelii wedtug świętego Jana ${ }^{17}$ i siedemdziesiąt cztery homilie do Pierwszego ${ }^{18}$ i Drugiego listu świętego Pawła do Koryntian ${ }^{19}$. Spośród homilii drugiego rodzaju natomiast należy wspomnieć o homiliach o tajemnicy Boga przeciwko aecjanom ${ }^{20}$ oraz o dwunastu katechezach chrzcielnych ${ }^{21}$.

Następnie mowy Janowe dzieli się na cztery podgrupy, to jest na mowy moralne, mowy na święta liturgiczne, mowy pochwalne oraz mowy okolicz-

patrystyczna: 1901-2016. Polskie thumaczenia tekstów starochrześcijańskich pierwszego tysiąclecia, Kraków 2017, s. 527-528.

13 Iohannes Chrysostomus, Expositiones in psalmos, PG 55, CPG 4413. Mamy po polsku dwie z tych homilii i fragmenty z kilku pozostałych. Zob. Stawiszyński, Bibliografia patrystyczna, s. 528.

14 Iohannes Chrysostomus, De Anna sermones 1-5, PG 54, 631-676, CPG 4411.

15 Zob. punkt 3.1 niniejszego wstępu.

16 Iohannes Chrysostomus, In Matthaeum homiliae 1-90, PG 57-58, CPG 4424, tł. Św. Jan Chryzostom, Wykład Ewangelii św. Mateusza w 90 homiliach zawarty, t. 1-3, tł. J. Krystyniacki, Lwów 1886. Tłumaczenie to wielokrotnie było przedrukowywane, zostało też uwspółcześnione. Zob. Stawiszyński, Bibliografia patrystyczna, s. 529-535.

17 Iohannes Chrysostomus, In Iohannem homiliae 1-88, PG 59, 23-482, CPG 4425. Po polsku jest tylko jedna z tych homilii, jedenasta, i fragmenty z niektórych pozostałych. Zob. Stawiszyński, Bibliografia patrystyczna, s. 535-536.

18 Iohannes Chrysostomus, In epistulam I ad Corinthios argumentum et homiliae 1-44, PG 51, CPG 4428. W polskim przekładzie są tylko dwie z tych homilii i fragmenty z wybranych pozostałych. Zob. Stawiszyński, Bibliografia patrystyczna, s. 537-538.

19 Iohannes Chrysostomus, In epistulam II ad Corinthios argumentum et homiliae 1-30, PG 51 oraz 61, 9-61, CPG 4429, tł. Św. Jan Chryzostom, Homilie do drugiego listu św. Pawła do Koryntian, tł. A. Paciorek, Biblia Ojców 1, Częstochowa 2019.

20 CPG 4318; PG 48, 701-812. Po polsku mamy fragmenty tych mów. Zob. Stawiszyński, Bibliografia patrystyczna, s. 513.

${ }^{21}$ CPG 4460-4472. Dysponujemy trzema kolekcjami katechez chrzcielnych Złotoustego: (1) Joannes Chrysostomus, Catecheses ad illuminandos, ed. A. Wenger, Sources Chrétiennes 50bis, Paris 1970, s. 107-260, (2) Jean Chrysostome, Trois Catéchèses baptismales, ed. A. Piédagnel, Sources Chrétiennes 366, Paris 1990, s. 110-242, (3) Iohannes Chrysostomus, Catecheses ad illuminandos, PG 49, 223-240, tł. Św. Jan Chryzostom, Katechezy chrzcielne (homilie katechetyczne do tych, którzy mają być oświeceni oraz do neofitów), U źródeł Katechumenatu 1, tł. W. Kania, opr. M. Starowieyski, Lublin 1993, s. 23-118; Św. Jan Chryzostom, Katechezy chrzcielne (homilie katechetyczne do tych, którzy maja otrzymać chrzest [zostać oświeceni] oraz do neofitów 9-12), U źródeł Katechumenatu 2, tł. W. Kania, opr. M. Starowieyski, Lublin 1994, s. 9-68. 
nościowe. Wśród pierwszych mamy między innymi perory o pokucie ${ }^{22}$, przeciwko noworocznym praktykom zabobonnym ${ }^{23}$ oraz te, w których Złotousty gromi wiernych chodzących zamiast na liturgię to do teatru albo cyrku ${ }^{24}$. Wśród mów drugich znajdujemy przykładowo Janowe wystąpienia bożonarodzeniowe $e^{25}$, wielkoczwartkowe ${ }^{26}$, wielkopiątkowe ${ }^{27}$ czy wielkanocne ${ }^{28}$. Z kolei spośród laudacji przytoczmy - exempli gratia - siedem pochwał świę-

22 Iohannes Chrysostomus, De paenitentia homiliae 1-9, PG 49, 277-350, CPG 4333.

23 Iohannes Chrysostomus, De kalendas, PG 48, 953-962, CPG 4328, tł. Św. Jan Chryzostom, Homilia na Nowy Rok na temat słów Apostoła: „, Czyńcie wszystko na chwałe Boża”, w: Św. Jan Chryzostom, Homilie i kazania wybrane, Pisma Starochrześcijańskich Pisarzy 8, tł. W. Kania, opr. J.S. Bojarski, Warszawa 1971, s. 182-194.

24 Iohannes Chrysostomus, Contra ludos et theatra, PG 56, 263-270, CPG 4422 , tł. Św. Jan Chryzostom, Mowa przeciw tym, co opuściwszy kościót, pobiegli na wyścigi konne i widowiska teatralne, PSP 8, s. 175-181.

25 Iohannes Chrysostomus, In diem natalem, PG 49, 351-362, CPG 4334, tł. Św. Jan Chryzostom, Kazanie na Boże Narodzenie, PSP 8, s. 88-102.

26 Iohannes Chrysostomus, De proditione Iudae homiliae 1-2, PG 49, 373-392, CPG 4336. Po polsku są jedynie fragmenty. Zob. Stawiszyński, Bibliografia patrystyczna, s. 518.

27 Te wystąpienia mamy trzy: (1) Iohannes Chrysostomus, De coemeterio et de cruce, PG 49, 393-398, CPG 4337, tł. Św. Jan Złotousty, Homilia o nazwie cmentarza i krzyżu Chrystusowym, w: Św. Jan Złotousty, Dwadzieścia homilij i mów, tł. T. Sinko, Kraków 1947, s. 154-161; (2) Iohannes Chrysostomus, De cruce et latrone homilia 1, PG 49, 399-407, CPG 4338, tł. Św. Jan Złotousty, Homilia I o krzyżu i łotrze, w: Św. Jan Złotousty, Dwadzieścia homilij i mów, tł. T. Sinko, Kraków 1947, s. 162-175; (3) Iohannes Chrysostomus, De cruce et latrone homilia 2, PG 49, 407-418, CPG 4339, t1. Św. Jan Chryzostom, O krzyżu, o nawróconym łotrze i o modlitwie za nieprzyjaciót, tł. A. Paciorek, „Scripturae Lumen. Biblia i jej oddziaływanie” 3 (2011) s. 623-633.

28 Wystąpienia paschalne Jana mamy dwa: (1) Iohannes Chrysostomus, De resurectione d. n. Iesu Christi, PG 50, 433-442, CPG 4341, tł. Św. Jan Złotousty, Przeciwko pijakom i o zmartwychwstaniu - kazanie wielkanocne, w: Św. Jan Złotousty, Dwadzieścia homilij i mów, tł. T. Sinko, Kraków 1947, s. 176-188; (2) Iohannes Chrysostomus, Homilia in sanctum pascha, PG 52, 765-772, CPG 4408, tł. Św. Jan Chryzostom, Kazanie na Wielkanoc, PSP 8, s. 103-110. 
tego Pawła ${ }^{29}$ oraz pochwały Ignacego ${ }^{30}$, Eustachego i Melecjusza ${ }^{31}$, biskupów antiocheńskich. Wreszcie spośród mów okolicznościowych Jana wymieńmy tę, jaką wygłosił on w związku ze swoimi święceniami kapłańskimi ${ }^{32}$, oraz ważne dla nas i już wzmiankowane mowy z cyklu $O$ posagach $^{33}$.

Gdy chodzi o Chryzostomowe traktaty, to przyjmuje się je porządkować, wyodrębniając wśród nich sześć podgrup: najsłynniejszy bodaj traktat o kapłaństwie - De sacerdotio ${ }^{34}$; cztery traktaty o życiu monastycznym Ad Theodorum lapsum ${ }^{35}$, De compunctione ${ }^{36}$, Adversus oppugnatores vitae monasticae ${ }^{37}$, Comparatio regis et monachi ${ }^{38}$; trzy traktaty o dziewictwie i wdowieństwie - De virginitate ${ }^{39}$, Quod regulares feminae viris cohabitare non debeant ${ }^{40}$, Ad viduam iuniorem ${ }^{41}$; traktat o wychowaniu dzieci -

29 Iohannes Chrysostomus, De laudibus sancti Pauli apostoli homiliae 1-7, PG 50, 473-514, CPG 4344, tł. Św. Jan Chryzostom, Homilie panegiryczne o świętym Pawle, tł. J. Szwed-Kostecka, opr. A. Baron, Kraków 2015. Homilia pierwsza, trzecia i siódma mają jeszcze drugie tłumaczenie. Zob. Stawiszyński, Bibliografia patrystyczna, s. 520.

30 Iohannes Chrysostomus, In s. Ignatium martyrem, PG 50, 587-596, CPG 4351, tł. Św. Jan Chryzostom, Homilia o św. Ignacym Męczenniku, tł. K. Bielawski, „Materiały homiletyczne" 152 (1995) s. 4-22.

31 Iohannes Chrysostomus, De s. Meletio Antiocheno, PG 50, 515-520, CPG 4345, tł. Św. Jan Chryzostom, Kazanie o św. Melecjuszu, PSP 8, s. 162-167.

32 Iohannes Chrysostomus, Sermo cum presbyter fuit ordinatus, PG 48, 693-700, CPG 4317, tł. Św. Jan Chryzostom, Mowa w dniu święceń kapłańskich, PSP 8, s. 27-35.

33 Zob. przypis 7.

34 Iohannes Chrysostomus, De sacerdotio libri 1-6, PG 47, 623-692, CPG 4316, tł. Św. Jan Chryzostom, Dialog o kapłaństwie, Biblioteka Ojców Kościoła 23, tł. W. Kania, Kraków 1992.

35 Iohannes Chrysostomus, Ad Theodorum lapsum libri 1-2, PG 47, 277-316, CPG 4305, tł. Św. Jan Chryzostom, Do Teodora po jego upadku, tł. W. Kania, w: Św. Jan Chryzostom, Wybór pism: modlitwy liturgiczne; pisma o charakterze wychowawczym, Pisma Starochrześcijańskich Pisarzy 13, tł. H. Paprocki - W. Kania, opr. H. Paprocki A. Słomczyńska, Warszawa 1974, s. 192-238.

36 Iohannes Chrysostomus, De compunctione ad Stelechium libri duo, PG 47, 393-422, CPG 4308.

37 Iohannes Chrysostomus, Adversus oppugnatores vitae monasticae, PG 47, 319-386, CPG 4307.

38 Iohannes Chrysostomus, Comparatio regis et monachi, PG 47, 387-392, CPG 4500, tł. Św. Jan Chryzostom, Porównanie króla z mnichem, tł. W. Kania, PSP 13, s. 186-191.

39 Iohannes Chrysostomus, De virginitate, PG 48, 533-596, CPG 4313.

40 Iohannes Chrysostomus, Quod regulares feminae viris cohabitare non debeant, PG 47, 513-532, CPG 4312.

41 Iohannes Chrysostomus, Ad viduam iuniorem, PG 48, 399-410, CPG 4314. 
De inani gloria et de educandis liberis ${ }^{42}$; trzy traktaty o cierpieniu - Ad Stagirium a daemone vexatum ${ }^{43}$, Quod nemo laeditur nisi a seipso ${ }^{44}, A d$ eos qui scandalizati sunt ${ }^{45}$; oraz dwa traktaty przeciw poganom i Żydom De Babyla contra Iulianum et gentiles ${ }^{46}$, Contra Iudaeos et gentiles quod Christus sit deus ${ }^{47}$.

Ostatnia grupa pism Złotoustego to listy do około stu różnych adresatów. Mamy tych epistoł aż ponad dwieście ${ }^{48}$. Jakaś ich część dostępna jest w polskim thumaczeniu ${ }^{49}$.

\section{Pierwsza homilia Jana Chryzostoma do historii o Dawidzie i Saulu}

Tłumaczonej tu pierwszej z serii trzech homilii De Davide et Saule proponuję przyjrzeć się w dwóch odsłonach. Omówiwszy kwestię czasu i okoliczności jej - a właściwie całego tryptyku - powstania, przedstawię jej zawartość.

42 Iohannes Chrysostomus, De inani gloria et de educandis liberis, CPG 4455; Jean Chrysostome. Sur la vaine gloire et l'éducation des enfants, ed. A.-M. Malingrey, Sources Chrétiennes 188, Paris 1972, tł. Św. Jan Chryzostom, O wychowaniu dzieci, tł. W. Kania, PSP 13, s. 157-185.

43 Iohannes Chrysostomus, Ad Stagirium a daemone vexatum, PG 47, 423-494, CPG 4310.

44 Iohannes Chrysostomus, Quod nemo laeditur nisi a seipso, PG 52, 459-480, CPG 4400. Mamy dwa przekłady polskie tego dzieła: (1) Św. Jan Złotousty, Mowa o tym, że kto sam sobie nie szkodzi, nikt mu zaszkodzić nie może, w: Św. Jan Złotousty, Dwadzieścia homilij i mów, tł. T. Sinko, Kraków 1947, s. 280-307; (2) Św. Jan Chryzostom, Kto sam sobie nie szkodzi, temu nikt zaszkodzić nie może, tł. K. Kochańczyk, w: Bóg i zło. Pisma Bazylego Wielkiego, Grzegorza z Nyssy i Jana Chryzostoma, tł. K. Kochańczyk - J. Naumowicz M. Przyszychowska, opr. J. Naumowicz, Biblioteka Ojców Kościoła 23, Kraków 2004, s. 94-123.

45 Iohannes Chrysostomus, Ad eos qui scandalizati sunt, PG 52, 479-528, CPG 4401. Po polsku mamy fragmenty tego traktatu. Zob. Stawiszyński, Bibliografia patrystyczna, s. 522-523.

46 Iohannes Chrysostomus, De Babyla contra Iulianum et gentiles, PG 50, 533-572, CPG 4348.

47 Iohannes Chrysostomus, Contra Iudaeos et gentiles quod Christus sit deus, PG 48, 813-838, CPG 4326, t1. Św. Jan Chryzostom, Przeciwko Żydom i Hellenom. Wykazanie, że Chrystus jest Bogiem, na podstawie licznych o Nim proroctw, tł. J. Iluk, w: J. Iluk, Żydowska politeja i Kościót w imperium rzymskim u schyłku antyku, t. 1, Gdańsk 2006, s. 273-315.

48 Iohannes Chrysostomus, Epistulae, PG 52, 529-760, CPG 4402-4405.

49 Zob. Stawiszyński, Bibliografia patrystyczna, s. 523-527. 


\subsection{Data i okoliczności powstania}

Badacze zgadzają się co do roku powstania cyklu homiletycznego De Davide et Saule, jednomyślnie - od setek już zresztą lat - wskazując 387 rok $^{50}$. Spierają się natomiast o to, kiedy w owym 387 roku Chryzostom swoje trzy homilie do biblijnej historii opowiadającej o Dawidzie i Saulu wygłosił: czy przed Wielkanocą, czy po Wielkanocy, a zatem, bo takie konkretne propozycje przedkładają w swoich publikacjach uczeni, czy w Wielkim Poście, dokładniej zaś, czy w Wielkim Tygodniu, czy też krótko przed niedzielą Wniebowstąpienia ${ }^{51}$ Za tezą, że kazania ze zbiorku De Davide et Saule wygłoszone zostały w Wielkim Poście, opowiada się R.Ch. Hill, tłumacz rzeczonych homilii na język angielski ${ }^{52}$. Z kolei inne

50 Iohannis Chrysostomi De Davide et Saule homiliae tres, s. XII. Na temat w ogóle chronologii utworów Jana Chryzostoma, zob. W. Mayer, At Constantinople, how often did John Chrysostom preach? Addressing assumptions about the workload of a bishop, „Sacris Erudiri” 40 (2001) s. 83-105; W. Mayer, The Homilies of St. John Chrysostom: Provenance. Reshaping the Foundations, Orientalia Christiana Analecta 273, Roma 2005; P. Allen - W. Mayer, Chrysostom and the preaching of homilies in series: A new approach to the twelve homilies In epistulam ad Colossenses (CPG 4433), „Orientalia Christiana Periodica” 60 (1994) s. 21-39; P. Allen - W. Mayer, Chrysostom and the preaching of homilies in series: A re-examination of the fifteen homilies In epistulam ad Philippenses (CPG 4432), „Vigiliae Christianae” 49 (1995) s. 270-289; P. Allen - W. Mayer, The thirty-four homilies on Hebrews: The last series delivered by Chrysostom in Constantinople?, „Byzantion” 65 (1995) s. 309-348; P. Allen - W. Mayer, Traditions of Constantinopolitan preaching. Towards a new assessment of where Chrysostom preached what, „Byzantinische Forschungen" 24 (1997) s. 93-114.

51 Całkiem dobrze można się w tym sporze zorientować, zapoznając się z recenzjami edycji homilii Chryzostoma De Davide et Saule oraz tłumaczenia tychże homilii na język włoski: Iohannis Chrysostomi De Davide et Saule homiliae tres; F.P. Barone, Giovanni Crisostomo. Omelie su Davide e Saul, Collana di Testi Patristici 200, Rome 2008. Zob. W. Mayer, Barone (F. P.) (ed.) „Iohannis Chrysostomi De Davide et Saule homiliae tres”. (,, Corpus Christianorum Series Graeca” 70.) Pp. lxxxii + 83. Turnhout: Brepols, 2008. Cased, €85. ISBN: 978-2-503-527, „The Classical Review. New Series”, 60 (2010) 2, s. 612-613; J. Maxwell, Francesca Prometea Barone (ed.), „,Iohannis Chrysostomi De Davide et Saule homiliae tres". Corpus christianorum. Series Graeca; 70. Turnhout: Brepols, 2008, pp. Lxxxi + 77, ISBN 9782503527970, „ExClass” 14 (2010) s. 417-418; G. Masi, Giovanni Crisostomo, „,Omelie su Davide e Saul”, traduzione e note di Francesca Prometea Barone (,, Collana di Testi Patristici”, 200), Roma, Città Nuova Editrice, 2008, 138 pp., „Schede Medievali. Sommario” 47 (2009) s. 259-269.

52 R.Ch. Hill, St. John Chrysostom. Old Testament Homilies, t. 1, Brookline 2003; R.Ch. Hill, Chrysostom's Homilies on David and Saul, „St. Vladimir's Theological Quarterly" 44 (2000) s. 123-141. 
stanowisko zajmują B. de Montfaucon, badacz żyjący w latach 1655-1741, pierwszy wydawca dzieł wszystkich Chryzostoma, którego opus przedrukował potem u siebie J.-P. Migne, oraz - obecnie - F.P. Barone, autorka nowego wydania krytycznego De Davide et Saule ${ }^{53}$ i thumaczka tegoż Chryzostomowego utworu na język włoski ${ }^{54}$.

Dwie zasadnicze opinie co do daty powstania interesującego nas dzieła są konsekwencją dwóch możliwych sposobów odpowiedzi na pytanie o to, do którego swojego kazania odnosi się Chryzostom w pierwszej części zajmującej nas tu pierwszej homilii z serii De Davide et Saule, wtedy miano-

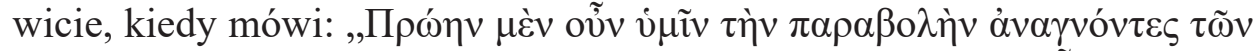

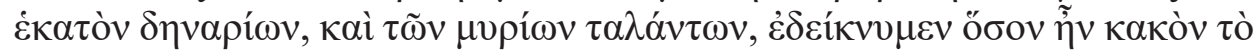
$\mu \nu \eta \sigma ı \kappa \alpha \kappa \varepsilon i v ”$ („Ostatnio więc, przeczytawszy przypowieść o stu denarach i dziesięciu tysiącach talentów, wyjaśnialiśmy wam, jak wielkim złem jest rozpamiętywanie krzywd") - i potem, trochę dalej, gdzie padają słowa na-

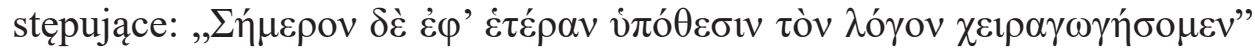
(,W dzisiejszej mowie podejmiemy natomiast temat nowy”). Można bowiem przyjąć, że Chryzostom ma tu na myśli albo swoje kazanie De decem milium talentorum debitore ${ }^{55}$, albo dwudziestą mowę z cyklu De statuis ${ }^{56}$.

Montfaucon przyją - a za nim zwykło się tak do czasu uznawać jednogłośnie i powszechnie - iż Janowa wzmianka o lekturze i objaśnieniu przypowieści o litościwym panu i nielitościwym dłużniku ${ }^{57} \mathrm{~W}$ pierwszej z homilii De Davide et Saule odnosi się do kazania De decem. Takie stanowisko wydaje się naturalne i całkowicie zrozumiałe, zważywszy przede wszystkim ów zasadniczy fakt, że podczas kiedy kazanie De decem stanowi rozbudowany komentarz do przypowieści, jak ją krótko nazywamy, o niemiłosiernym dłużniku, w mowie dwudziestej z cyklu $O$ posagach Jan właściwie tylko w paru słowach do tej historii ewangelijnej nawiązuje. To nawiązanie trudno byłoby, mówiąc szczerze, określić mianem wyjaśnienia, a tak je przecież Chryzostom w pierwszej z homilii O Dawidzie

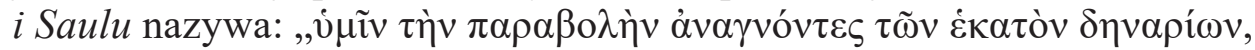

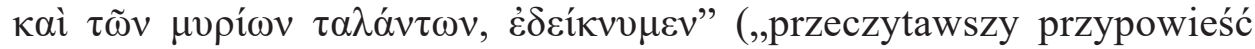
o stu denarach i dziesięciu tysiącach talentów, wyjaśnialiśmy wam”). Ponieważ zaś Montfaucon uważa, że homilia De decem wygłoszona zo-

53 Iohannis Chrysostomi De Davide et Saule homiliae tres.

54 F.P. Barone, Giovanni Crisostomo.

55 Iohannes Chrysostomus, De decem milium talentorum debitore, PG 51, 17-30, CPG 4368.
56 Zob. przypis 7.
57 Mt 18,23-35. 
stała przez Jana po Wielkanocy, nieco przed piątą niedzielą wielkanocną,

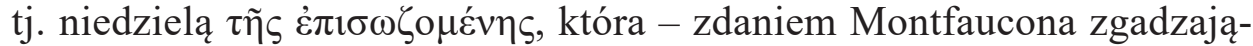
cego się w tym względzie z Leo Allatiusem - poprzedzała w Antiochii święto Wniebowstąpienia ${ }^{58}$, przyjmując jednocześnie, że w samą rzeczoną niedzielę $\tau \tilde{\eta} \varsigma \dot{\varepsilon} \pi 1 \sigma \omega \zeta o \mu \varepsilon ́ v \eta \varsigma$ wygłosił Chryzostom dziewiętnastą mowę z serii De statuis, wnioskuje, iż kazania z cyklu De Davide et Saule głosił Chryzostom w tym właśnie czasie: najogólniej, a zarazem możliwie precyzyjnie mówiąc, około niedzieli $\tau \tilde{\eta} \varsigma \dot{\varepsilon} \pi \iota \sigma \omega \zeta o \mu \varepsilon ́ v \eta \varsigma$ - albo przed tą niedzielą, ale po dniu, w którym wygłosił kazanie De decem, albo po tej niedzieli, albo w ten sposób, że zaczął przed niedzielą, a skończył po niedzieli. Gdy natomiast chodzi o terminus ante quem, to Montfaucon sądzi, iż stanowi go mniej więcej uroczystość Wniebowstąpienia Pańskiego. Jest bowiem przekonany, że jeszcze przed tym świętem - dokładnie dwa dni przed tym świętem - rozpoczął Jan wygłaszać cykl pięciu homilii De Anna ${ }^{59}$.

$\mathrm{Na}$ jakiej podstawie Montfaucon sporządza taką chronologię Chryzostomowego przepowiadania $\mathrm{w}$ interesującym nas czasie? Punkt wyjścia stanowi dla niego fakt - o czym pisze w swoim monicie, którym poprzedził cykl homilii $O$ Annie $e^{60}$ - iż po Wielkanocy 387 roku Złotousty przez wiele dni (multis diebus), złożony chorobą, pozostawał w domu (Chrysostomus tum aeger domi manebat), zawieszając oczywiście swoją aktywność kaznodziejską. A jako że kazanie De decem rozpoczyna Jan od usprawiedliwienia swojej nieobecności, Montfaucon uważa, że było ono wygłoszone przez Chryzostoma jako pierwsze po tym, jak powrócił on do zdrowia. Także na początku dziewiętnastej homilii De statuis Jan wspomina swoją chorobę, a zatem, rozumuje Montfaucon, homilia ta musiała zostać wygłoszona w tym samym czasie, co kazanie o przypowieści o nielitościwym dłużniku: Montfaucon rozstrzyga, że Złotousty wygłosił ją, jak

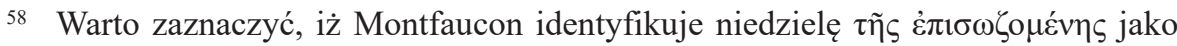
piątą niedzielę wielkanocną, choć skądinąd wiadomo, że w Kościele antiocheńskim taką nazwę nosiła albo niedziela przed, albo niedziela po dniu wspomnienia wniebowstąpienia Pańskiego. Samo wniebowstąpienie, jak się wydaje, nazywano tam chyba $\dot{\eta} \dot{\varepsilon} \pi \imath \omega \zeta o \mu \varepsilon ́ v \eta$. Zob. na ten temat np. Podręczna encyklopedia kościelna, red. J. Archutowski R. Archutowski, Poznań - Warszawa 1914, s. 378; K. Jaworski, Wniebowstapienie Pańskie w praktyce liturgicznej Kościoła, „Studia Paradyskie” 23 (2013) s. 90; The Cyclopedia of Biblical, Theological, and Ecclesiastical Literature, ed. J. Strong - J. McClintock, New York 1880, s.v. episozomene, w: https://www.biblicalcyclopedia.com/E/episozomene. html (dostęp: 06.06.2020).

59 Zob. przypis 14.

60 B. de Montfaucon, Ad sermones quinque in Annam monitum, PG 54, 631-632. 
powiedzieliśmy, w niedzielę $\tau \tilde{\eta} \varsigma ~ \dot{\varepsilon} \pi 1 \sigma \omega \zeta o \mu \varepsilon \dot{v} \eta \varsigma^{61}$. Uzasadniając taką konstatację, można wskazać na fakt, iż Jan zwraca się w owej perorze do słuchaczy, pośród których są syryjskojęzyczni wieśniacy z terenów leżących dookoła Antiochii, thumnie przybyli do miasta wraz ze swoimi duszpasterzami na zorganizowaną tam liturgię ${ }^{62}$. Wiemy bowiem, że rolnicy spod Antiochii udawali się do miasta na Eucharystię w ważniejsze dni i w święta $^{63}$. Odnośnie do datacji początku serii $O$ Annie zaś opiera się Montfaucon na jej fragmencie wstępnym, w którym Jan przedstawia pokrótce wydarzenia od powrotu z Konstantynopola do domu biskupa Flawiana, co miało miejsce tuż przed Paschą, aż do wizyty w Antiochii wieśniaków zamieszkujących tereny dookoła niej. Ponadto zaznacza Montfaucon, że w pierwszej homilii De Anna nie wspomina już Złotousty o swojej chorobie. Zwraca też uwagę, iż homilie Jana o Annie nie są utrzymane w pełnej niepewności i napięcia atmosferze oraz że szóste kazanie z tego cyklu, które na przestrzeni wieków się zagubiło, zostało z pewnością wygłoszone już po uroczystości Zesłania Ducha Świętego ${ }^{64}$.

Z kolei R.Ch. Hill twierdzi, że wzmianka z pierwszej homilii z cyklu De Davide et Saule o przypowieści o nielitościwym dłużniku dotyczy dwudziestej homilii z serii De statuis, choć zaznacza, że możliwe jest także inne rozstrzygnięcie tej kwestii ${ }^{65}$. Nie przeszkadza mu, iż w owej homilii dwudziestej z cyklu $O$ posagach naprawdę niewiele jest mowy o rzeczonej opowieści biblijnej, co już w naszym wywodzie spostrzegliśmy, i nazywa to niewiele pełniejszym czy bardziej wyczerpującym komentarzem (more fully commented). A ponieważ Hill przyjmuje, że dwudziesta spośród homilii De statuis wygłoszona była mniej więcej tydzień przed powrotem z Konstantynopola biskupa Flawiana, sądzi, iż mowy O Dawidzie i Saulu zostały wygłoszone w Wielkim Tygodniu 378 roku. Co ciekawe i warte podkreślenia, podstawowym argumentem za takim rozstrzygnięciem kwestii datacji cyklu De Davide et Saule jest dla Hilla jego interpretacja tegoż

${ }^{61}$ Niedziele tę - dodajmy tu może na marginesie - F. van de Paverd datuje na 12

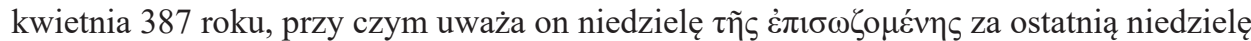
wielkopostną, nie wspominając już o tym, że datacja kolejnych homilii O posagach jest rzeczą dyskusyjną. Zob. F. van de Paverd, St. John Chrysostom. The Homilies on the Statues, Orientalia Christiana Analecta 239, Roma 1991.

62 W tym kontekście zob. np. P. Szczur, Jan Chryzostom a duszpasterstwo osób nie mówiących po grecku, „Vox Patrum” 55 (2010) s. 600-605.

63 S.-I. Lee, Jesus and Gospel Traditions in Bilingual Context: A Study in the Interdirectionality of Language, Berlin - Boston 2012, s. 167.

64 Montfaucon, Ad sermones quinque in Annam monitum.

65 Hill, Chrysostom's Homilies on David and Saul, s. 5, 135. 
cyklu. Wszak sądzi on, iż tryptyk ów w pierwszym rzędzie stanowi wielki komentarz do wydarzeń bieżących - komentarz jednakże osobliwy, w którym o tych wydarzeniach mówi się jedynie nie wprost, metaforycznie, aluzyjnie. W Dawidzie, wpierw rozgniewanym na Saula, który wobec niego zawinił, i podjudzanym przez swoich żołnierzy do zabicia króla, a potem litującym się nad swoim panem, widzi Hill rozsierdzonego przez bunt antiocheńczyków cesarza Teodozjusza, nagabywanego przez swoich urzędników do surowości względem buńczucznych i nieposłusznych podwładnych, który winnym grzechu obrazy cesarskiego majestatu mieszkańcom Antiochii w ostatecznym rozrachunku okazuje jednak miłosierdzie. W ten sposób czyta Hill cykl De Davide et Saule jako jeden z elementów składających się na działalność podjętą przez antiocheńskich duchownych, kapłana Chryzostoma i biskupa Flawiana, która zmierzała do tego, by pojednać Teodozjusza i zrewoltowanych antiocheńczyków. Dla Hilla nie ulega wątpliwości, że homilie o Dawidzie i Saulu zostały przez Złotoustego tak pomyślane i zaplanowane i że tak też właśnie zostały przez jego słuchaczy w Wielkim Tygodniu 387 roku odczytane: jako zapowiedź cesarskiej łaski, zapowiedź wlewającą w ich strwożone i przestraszone tym, czego się dopuścili i co zaszło, serca nadzieję.

Z tym, co przedkłada Hill, nie zgadza się F. Barone. Autorka ta skłania się ku temu, co w temacie datacji De Davide et Saule ustalił Montfaucon, swoje stanowisko przedstawia we wstępie do opracowanej przez siebie edycji tegoż dzieła ${ }^{66}$. Dla podważenia propozycji Hilla wskazuje, że opis życia w Antiochii, jaki zawarł Chryzostom w piętnastej homilii z cyklu De statuis ${ }^{67}$, nie zgadza się ze słowami, które Złotousty wypowiada na początku trzeciej homilii z tryptyku poświęconego historii Dawida i Saula. Ze słów tych wynika bowiem, ponieważ gani w nich Jan tych, którzy wychodząc z liturgii, poszli do teatru, że życie w mieście biegnie swym normalnym trybem. A przecież wiadomo, że po lutowych zamieszkach życie w Antiochii na kilka tygodni zamarło w oczekiwaniu na ostateczną decyzję cesarską, o czym dowiadujemy się ze wspomnianej piętnastej mowy Złotoustego skierowanej do antiocheńczyków. Zatem, orzeka Barone, tryptyk De Davide et Saule nie mógł zostać wygłoszony w Wielkim Poście, dokładniej w Wielkim Tygodniu 387 roku, czyli wówczas, kiedy ostateczny werdykt Teodozjusza w sprawie antiocheńskiej jeszcze nie zapadł i kiedy

\footnotetext{
${ }^{66}$ Iohannis Chrysostomi De Davide et Saule homiliae tres, s. XI-XIX.

67 Zob. przypis 7.
} 
w związku z wyczekiwaniem na ów werdykt życie w syryjskiej metropolii zastygło.

Argument Barone przeciwko wysuniętej przez Hilla propozycji datacji utworu O Dawidzie i Saulu podważa z kolei W. Meyer w swojej recenzji edycji Iohannis Chrysostomi De Davide et Saule homiliae tres ${ }^{68}$. Zarzuca ona Barone, że rozważając kwestię czasu powstania zajmującego nas utworu, nie uwzględniła datacji mów Chryzostoma o posągach zaproponowanej w 1991 roku przez F. van de Paverda. Autor ten przyjął bowiem, że piętnaste kazanie o posągach wygłosił Jan 6 marca, a więc na koniec pierwszego tygodnia Wielkiego Postu 387 roku, czyli właściwie zaraz po lutowych rozruchach w Antiochii, kiedy życie publiczne w mieście całkowicie zamarło. Jednakże siedem tygodni później, kiedy Post się kończył - zauważa Mayer - atmosfera w mieście mogła się przecież znacznie poprawić, cesarskie restrykcje nie musiały być już wtedy wcale tak skrupulatnie przestrzegane i antiocheńczycy mogli powrócić już do swoich zwyczajnych rozrywek. Mayer konkluduje następująco: oczywiście nie oznacza to, że chronologia sporządzona przez Hilla jest poprawna, ale przynajmniej taki tok rozumowania pozwala stwierdzić, że nie jest ona niemożliwa, a że jest niemożliwa, chciałaby przyjąć Barone.

Oprócz przedstawionych dwóch zasadniczych możliwych sposobów określenia dokładniejszej daty wygłoszenia przez Chryzostoma trzech kazań De Davide et Saule można by wskazać w gruncie rzeczy jeszcze jeden. W 2000 roku bowiem A. Valevicius opublikował artykuł ${ }^{69}$, w którym zaproponował, aby do zbioru dwudziestu jeden - jak się przyjmuje za Montfaucontem i Migne'em - mów do antiocheńczyków o posągach włączyć jeszcze trzy kazania Złotoustego, mianowicie In Psalmum 14570, katechezę chrzcielną z Wielkiej Środy 387 roku $^{71}$ oraz, co w kontekście datacji De Davide et Saule najistotniejsze, De decem ${ }^{72}$. Oczywiście propozycja Valeviciusa nie jest nienastręczającą żadnych trudności: S. Longosz

68 Mayer, Barone (F. P.), s. 612-613.

69 A. Valevicius, Les 24 homélies „De statuis” de Jean Chrysostome. Recherches nouvelles, ,Revue des études augustiniennes” 46 (2000) s. 83-91.

70 Iohannes Chrysostomus, Expositio in Psalmum 145, PG 55, 519-528, CPG 4415.

71 Iohannes Chrysostomus, Ad illuminandos catechesis 2, PG 49, 231-240, CPG 4464, tł. Św. Jan Chryzostom, Katecheza dwunasta, w: Św. Jan Chryzostom, Katechezy chrzcielne (homilie katechetyczne do tych, którzy maja otrzymać chrzest [zostać oświeceni] oraz do neofitów 9-12), U Źródeł Katechumenatu 2, tł. W. Kania, opr. M. Starowieyski, Lublin 1994, s. 51-68.

72 Zob. przypis 55. 
wskazuje chociażby, iż żadna z owych trzech homilii, które w przekonaniu Valeviciusa winny być zaliczone do serii De statuis, nie zawiera odniesień do antypodatkowej rebelii w Antiochii w 387 roku - w konsekwencji Longosz stwierdza, że zasadnie można do serii o posągach włączyć jedynie ową katechezę chrzcielną ${ }^{73}$. Niemniej jednak propozycja Valeviciusa godna jest uwagi, ponieważ gdyby przystając na nią, uznać, iż De decem wygłosił Złotousty w Wielkim Poście 387 roku, to powstałaby możliwość uzgodnienia ze sobą jednego i drugiego zaprezentowanego powyżej ciągu myślowego, zmierzającego do ustalenia daty wygłoszenia przez Jana tryptyku o Dawidzie i Saulu. Być może zebrawszy także inne wątki pojawiające się w ramach dyskusji odnośnej kwestii - na przykład to, na co zwróciła uwagę W. Mayer - i przepracowawszy je, udałoby się wówczas zebrać jakąś pulę argumentów, która w jakiejś mierze zdołałaby uzasadnić tezę, że z tryptykiem De Davide et Saule wystąpił Chryzostom przed Wielkanocą 387 roku. Tymczasem trudno cokolwiek, choćby względnie tylko pewnego, w temacie skonstatować.

Gdy chodzi o datację $O$ Dawidzie $i$ Saulu, to trzeba odpowiedzieć na jeszcze jedno pytanie, mianowicie o to, jaki jest stosunek czasowy pomiędzy kolejnymi kazaniami składającymi się na ten krótki cykl. Otóż przyjmuje się, że homilie te najzwyczajniej następowały po sobie, jedna po drugiej i że w związku z tym głoszone były dzień po dniu. Jako argument za takim stwierdzeniem wskazuje się na fakt, iż Jan bardzo dokładnie podąża w swoim kaznodziejskim wywodzie za tekstem biblijnym, nie czyniąc właściwie żadnych przeskoków i niczego z niego nie pomijając ${ }^{74}$. Zasadniczo można się zgodzić z takim stanowiskiem, choć - ze strony wtórej patrząc - można by podjąć z nim niejaką polemikę. Podczas gdy pierwsza i druga homilia z cyklu $O$ Dawidzie $i$ Saulu bardzo płynie łączą się ze sobą, trzecia zaczyna się od dość rozbudowanej dygresji na temat chodzenia do teatru i zażywania, by tak rzec, teatralnych przyjemności. Być może nie należy do tego faktu przywiązywać zbyt wielkiej wagi. Ale z drugiej strony prawdopodobnie dałoby się go wykorzystać, chcąc uzasadnić twierdzenie, iż między drugą a trzecią homilią z zajmującej nas tu serii miała miejsce jakaś dłuższa przerwa. Przykładowo, uwzględniwszy to, co powiedziano wyżej, można by próbować utrzymywać, że pierwsze dwie homilie Złotousty wygłosił przed

73 S. Longosz, Św. Jan Chryzostom, Mowy do Antiocheńczyków o posagach, przekład i komentarz Jan Iluk, Gdańsk 2017, Wydawnictwo Uniwersytetu Gdańskiego, ss. $X X V I+282$, ,Vox Patrum” 70 (2018) s. 725.

74 Iohannis Chrysostomi De Davide et Saule homiliae tres, s. XI-XIX. 


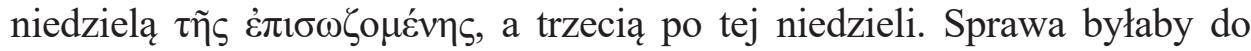
szczegółowej analizy i do rozpatrzenia.

\subsection{Omówienie treści}

F. Barone podzieliła tekst pierwszej homilii z cyklu De Davide et Saule na siedem części. Przedstawiając więc zawartość tej mowy, warto uwzględnić - dla porządku, z konieczności zorganizowania w jakiś sposób materiału - ów podział na rozdziały wprowadzony przez Barone. Zresztą podział ten jest bardzo dobrze przeprowadzony: pomaga w głębszym odczytaniu i zrozumieniu tekstu.

Część pierwsza ma naturalnie charakter wprowadzający. Zapowiada tu Jan, iż przez kilka kolejnych dni - a więc wyczerpująco i obszernie będzie mówił o gniewie, - chodzi mu najprawdopodobniej, jak można się domyślać, o gniew Saula - który uznaje za chorobę duszy. Jak chorobę cielesną długo trzeba nieraz leczyć, podobnie zdarza się i w przypadku choroby duchowej. Jan zapowiada, iż będzie głosił słowo Boże dopóty, dopóki nie zobaczy, jak jego nauka przechodzi u jego słuchaczy w czyn - dzięki takiemu postępowaniu podobny będzie do nauczyciela. Nawiązując do kazania o przypowieści o nielitościwym dłużniku, Złotousty wskazuje drugi - stwierdzić należy: właściwy - temat swojej mowy: skoro przedstawił swoim słuchaczom wspaniałomyślną postawę pana, który podarował swojemu dłużnikowi ogromny dług, teraz chce podać inny jeszcze przykład takiej postawy. Jako ów drugi przykład wybiera czyn Dawida, mianowicie darowanie przez niego życia Saulowi, o którym czytamy w Pierwszej Księdze Samuela. Złotousty wybiera Dawida, bo z jednej strony otrzymał on od samego Boga świadectwo o swojej wielkoduszności, z drugiej zaś strony dlatego, bo jest postacią Starego Testamentu, która na długo zanim na świat przyszedł Chrystus, zrealizowała Jego, a zarazem nowotestamentalny ideał człowieczeństwa.

Część drugą swojej mowy Złotousty rozpoczyna od wyliczenia dobrodziejstw, jakimi Dawid obdarzył Saula. Wskazuje, że mimo młodego wieku włączył się w wojnę i, co więcej, że w imieniu wszystkich, pokonując wiele przeszkód, w tym podniósłszy załamanego położeniem, w jakim się znalazł, Saula na duchu, stanął do walki z Goliatem i pojedynek ten wygrał. Ale jak odwdzięczył się za to wszystko Saul Dawidowi, pyta Chryzostom. Samym i tylko złem. Zamiast oddać Dawidowi swoją koronę, na co ten niewątpliwie swoim postępowaniem i bohaterstwem zasłużył. Saul odpła- 
cił się Dawidowi zdaniem Jana złem, wszak zazdrościł mu, że został pochwalony przez kobiety za odniesione zwycięstwa, a przecież, powiada Złotousty, pochwały te były jak najbardziej na miejscu. Jeśli w takiej sytuacji miałby się ktoś gniewać, to gniewać winien się Dawid, bo wszystkiego dokonał sam, a został pochwalony tylko za część swoich czynów.

W części trzeciej swojego kazania Chryzostom zajmuje się postawą Dawida wobec króla, w jakiej ten trwał pomimo krzywd, których doznał od Saula. Złotousty zwraca uwagę na to, że, po pierwsze, Dawid nie stał się wobec Saula arogancki ani też w żaden sposób nie wynosił się ponad niego, ale trwał w pokorze, bardzo dbając o to, aby w niczym nie uchybić władcy i by we wszystkim zajmować wobec niego właściwą sobie pozycję poddanego. Po drugie, znosząc ze strony Saula rozmaite przykrości, Dawid był względem niego wielkoduszny i w jego imieniu prowadził zwycięskie kampanie wojenne. A jakby tego było mało, to wtedy, kiedy Saul popadał w szaleństwo, łagodził jego obłęd grą na instrumencie strunowym. Lecz Dawida ze strony Saula spotkało jeszcze coś gorszego, konstatuje, po trzecie, Chryzostom. Mianowicie kilka razy Saul usiłował go zabić, rzucając weń oszczepem. Lecz i takie postępowanie Saula zniósł Dawid niewzruszenie i ze spokojem, niczego się od Saula nie domagając. W końcu, stwierdza Jan, Saul postanowił pozbyć się Dawida podstępem, proponując mu małżeństwo ze swoją córką. Aby jednak do zawarcia związku mogło dojść, na mocy jego postanowienia Dawid musiał ofiarować mu w ślubnym darze sto napletków obcoplemieńców. Składając Dawidowi taką propozycję, Saul miał bowiem nadzieję, komentuje Biblię Chryzostom, że polegnie on w bitwie.

W pierwszej części rozdziału czwartego swojej homilii Złotousty kończy wątek małżeństwa Dawida z królewską córą, bardziej jeszcze naświetlając w ten sposób ohydę Saula. Kiedy bowiem spełniwszy podłe życzenie swego pana, pojął już Dawid za żonę Melchol, Saul znów celował do niego włócznią. Zauważa w tym miejscu Jan, iż gdyby Dawid zdecydował się zabić Saula, nie dopuściłby się niczego złego w świetle prawa, to wszak nakazywało odpłacić się złem za zło, lecz on w ten sposób nie postąpił. A co zrobił? Z troski o króla, by nie prowokować go do gniewu, zdecydował się zniknąć sprzed jego oczu i poszedł na dobrowolną banicję. Jednakże nic to nie pomogło, kontynuuje Chryzostom. Saul bowiem szukał Dawida, chcąc go zamordować. Aż w końcu w jaskini to nie Dawid wpadł w ręce Saula, ale Saul, śpiąc, dostał się w ręce Dawida. W końcowej sekwencji tej części mowy Złotousty koncentruje się na opisaniu tego, co, jak przypuszcza, musiało się dziać w jaskini: jak żołnie- 
rze Dawida musieli napierać na niego, aby zatopił swój sztylet w piersi Saula, i jak Dawid nie tylko samego siebie powstrzymał od popełnienia tego czynu, ale i swoich ludzi odwiódł od jego dokonania, skłaniając ich do tego, aby tak jak on oszczędzili króla. Wydaje się, że to miejsce stanowi punkt kulminacyjny całej homilii.

Rozdział piąty zasadniczo poświęcony jest temu, co działo się w jaskini pomiędzy Dawidem a jego żołnierzami. Jan stara się tu, kontynuując myśl podjętą na końcu rozdziału poprzedniego, uzmysłowić słuchaczom wielkość czynu Dawida, która polegała w jego ocenie na tym, że zdołał przekonać swoją drużynę, aby wobec Saula zachowała się tak jak on. Prezentuje tu Chryzostom swój pogląd w bardzo rozbudowanym wywodzie dzięki powolnemu odkrywaniu strategii perswazyjnej zastosowanej przez żołnierzy wobec Dawida, umiejętnie stopniując emocje: najpierw przypomnieli wojacy swemu dowódcy wszystkie niesprawiedliwości, jakich zaznał on z rąk Saula, a kiedy spostrzegli, że w ogóle on na to nie zważa, powołali się na Boga, mówiąc Dawidowi, iż to sam Bóg wydaje mu teraz Saula, aby pozbawiając go życia, zemścił się na nim ze wszelkie doświadczone odeń zło. Dość obszernie w tym rozdziale występuje Złotousty przeciwko dwóm twierdzeniom, przy których ktoś jego zdaniem mógłby chcieć obstawać, to jest przeciwko twierdzeniu, że nie jest niczym dziwnym, iż ten, który zostaje królem, postanawia oszczędzić swojego nieprzyjaciela, oraz przeciwko tezie, że Dawidowi przyszło się powstrzymać od zabicia Saula niezmiernie łatwo. Jan uważa, że wcale nie było dla Dawida proste pohamować się od królobójstwa. I wyjaśnia, że litując się nad Saulem, nie objął jeszcze Dawid tronu.

W partii szóstej swojej mowy Chryzostom zaznacza wpierw, że Dawid przestraszył się tego, co uczynił Saulowi, że mianowicie odciął frędzel od jego szaty, co świadczy o jego wielkiej cnotliwości i łagodności. Powiada tu Jan, że Dawida należałoby określać mianem anioła. Potem Złotousty koncentruje się na sposobie, w jaki Dawid odnosił się do Saula, nazywając go namaszczonym przez Pana i swoim panem - to nazewnictwo, skłaniając go do życzliwości względem Saula, w końcu zmieniło jego nastawienie do króla. Jan objaśnia, jak serdeczne odnoszenie się do drugiego człowieka może niepostrzeżenie ukształtować dobre usposobienie względem niego.

W ostatniej części kazania Jan przypomina swoim słuchaczom, że chodzi o to, żeby naśladować postawę Dawida. W tym celu trzeba sobie jego historię jakby namalować w myślach. Złotousty stwierdza, iż historie biblijne, kiedy są czytane i rozważane, okazują się bardzo pouczające, przy- 
nosząc rozmaite cenne wskazówki w każdej właściwie dziedzinie ludzkiego życia. Ostatecznie, powiada, nie jest możliwe, ,żeby dusza obeznana z tymi historiami kiedykolwiek mogła zostać pokonana przez namiętność". Chryzostom kończy swoje kazanie, zachęcając odbiorców do robienia dobrego użytku ze swojego życia, a nie marnowania go „,na brednie niestosowne i niepotrzebne".

\section{Wydania krytyczne tekstu}

Iohannes Chrysostomus, De Davide et Saule homiliae tres, PG 54, 675-708.

Iohannis Chrysostomi De Davide et Saule homiliae tres, ed. F.P. Barone, Corpus Christianorum. Series Graeca 70, Turnhout 2008.

\section{Nowożytne przekłady tekstu}

\section{Język angielski}

Hill R.Ch., St. John Chrysostom. Homilies on Hannah, David and Saul, St. John Chrysostom. Old Testament Homilies 1, Brookline $2003^{75}$.

\section{Język włoski}

Barone F.P., Giovanni Crisostomo. Omelie su Davide e Saul, Collana di Testi Patristici 200, Rome 2008.

\section{Przeklad}

[Homilia świętego ojca naszego Jana Chryzostoma, arcybiskupa konstantynopolitańskiego, o historii Dawida i Saula ${ }^{76}$ - o cierpliwości, o tym, że trzeba oszczędzać nieprzyjaciół i że nie wolno mówić źle o rządzących.]

1. Ilekroć jakaś długotrwała i wysoka gorączka trawi ciało, potrzeba wiele czasu i trudu oraz rozległej wiedzy o lekarstwach, ażeby bezpiecznie ją obniżyćc ${ }^{77}$. Tak samo, można powiedzieć, dzieje się i w przypadku duszy.

75 Tłumaczenie to opracowane zostało na podstawie tekstu podanego przez Migne’a.

76 Niniejsze tłumaczenie sporządzone zostało w oparciu o edycję krytyczną tekstu autorstwa F.P. Barone.

77 Zaczyna Chryzostom swoją homilię - dla przykucia i pozyskania uwagi swoich słuchaczy - od przykładu zaczerpniętego z codziennego życia. Nie jeden raz jeszcze po 
Za każdym bowiem razem, kiedy ktoś wytrzebić chce z duszy chorobę zastarzałą i od długiego już czasu duszę toczącą, nie wystarczy jedno- czy dwudniowa zachęta do tego, lecz bardzo często nawet przez wiele dni trzeba rozmawiać o tej sprawie, i to o tyle dłużej, o ile przemawialibyśmy do czyjeś nie ambicji i przyjemności, ale chęci zysku i korzyści. Dlatego, jak to obiecaliśmy, przez kilka kolejnych dni będziemy rozprawiać z wami na ten temat, mianowicie o gniewie. I o nim podług naszych możliwości będziemy prowadzić rozważanie w sposób ciągły. Wydaje mi się bowiem, że taki tok nauczania jest najlepszy: nie kończyć wywodów odnośnie do jakiejś kwestii aż ujrzymy, jak nasze rozważanie przechodzi w $\operatorname{czyn}^{78}$. Dzisiaj mam mówić o miłosierdziu, jutro o modlitwie, pojutrze o łagodności, następnego zaś dnia o pokorze ${ }^{79}$, jednakże żadnej z tych cnót nie wszczepię w słuchaczy, jeśli będę przeskakiwać z jednego tematu na drugi, a potem do jeszcze innego zagadnienia. Skoro zatem pragnę, aby to, co mówię, moi słuchacze wzięli ze sobą w swoją przyszłość, potrzeba, żebym nie zaprzestawał zachęcać do tych rzeczy i rozprawiać o nich i żebym dopóty nie rozpoczynał nowego tematu, dopóki nie zobaczę, jak moja wcześniejsza zachęta $\mathrm{w}$ moich odbiorcach się ukorzenia. Tak postępują również nauczyciele: dopiero wówczas uczą dzieci sylab, kiedy widzą, że znają już one litery alfabetu ${ }^{80}$.

taki przykład w niniejszym swoim kazaniu Złotousty sięgnie zgodnie ze swoją kaznodziejską praktyką czy metodyką. Zob. W. Ceran, Przyktady z życia wzięte w nauczaniu św. Jana Chryzostoma, w: Czasy Jana Chryzostoma i jego pasterska pedagogia, red. N. Widok, Opolska Biblioteka Teologiczna 105, Opole 2008, s. 155-166.

78 Mówi Jan w tym miejscu o jednej, jak się przyjmuje, z zasad składających się na jego pedagogię, mianowicie o regule, wedle której dany temat należy podejmować, kontynuując go w kilku kazaniach. Odnośnie do rzeczonej reguły, zob. P. Szczur, Zasady pedagogii św. Jana Chryzostoma w homiliach antiocheńskich, w: Czasy Jana Chryzostoma i jego pasterska pedagogia, red. N. Widok, Opolska Biblioteka Teologiczna 105, Opole 2008, s. 180.

79 Jak powiedziałem we wstępie (3.1 Data i okoliczności powstania), przyjmuje się, iż Jan głosił swoje homilie z cyklu De Davide et Saule raczej dzień po dniu. Problemem jest więc tu wymieniony dzień czwarty, albowiem homilii z serii O Dawidzie $i$ Saulu mamy jedynie trzy. Być może należy domniemywać, iż jakaś homilia, właśnie czwarta, nie zachowała się, być może ma tu na myśli Złotousty jakieś inne swoje kazanie, a być może, że Jan się tu po prostu pomylił.

80 Nauka czytania i pisania była zasadniczym elementem greckiej edukacji i trwała kilka lat. Np. Platon twierdził, że cztery lata na naukę czytania i pisania to wcale nie jest długo. Metodyka była taka: od tego, co najprostsze, przechodzono stopniowo do rzeczy coraz trudniejszych. Najpierw uczono osobno każdej z liter, potem zajmowano się sylabami, tymi znów w określonym porządku: w pierwszym rzędzie uczono sylab 
Ostatnio $^{81}$ więc przeczytawszy przypowieść o stu denarach i dziesięciu tysiącach talentów ${ }^{82}$, wyjaśnialiśmy wam, jak wielkim złem jest rozpamiętywanie krzywd ${ }^{83}$. Wspomniana historia opowiada bowiem, jak pan odwołał przebaczenie dane człowiekowi, który choć sam nie stracił dziesięciu tysięcy talentów, to jednak pogrążył innego, który był mu winien zaledwie sto denarów: jak pan cofnął temu człowiekowi łaskę, jak już uwolnionego od kary zaprowadził go znowu do sądu i jak stamtąd wtrącił go do więzienia, poddając go w ten sposób dożywotniej karze. W dzisiejszej mowie podejmiemy natomiast temat nowy. Wypada wszak - skoro przywołana przypowieść przedstawiła nam, jak stała się sprawiedliwość - żeby rozprawiając o łagodności i delikatności, i od siebie podać przykład ${ }^{84}$ owej pięknej filozofii ${ }^{85}$, by nauczać jej przez słowa

jednozgłoskowych, a następnie dwu-, trzy-, czterozgłoskowych itd. Więcej na ten temat, zob. np. H.-I. Marrou, Historia wychowania w starożytności, tł. S. Łoś, Warszawa 1969; W.M. Bloomer, A Companion to Ancient Education, Hoboken 2015.

81 Прஸ́ๆv znaczy 'niedawno, ostatnio, dopiero co, przedwczoraj, niegdyś'. Zob.

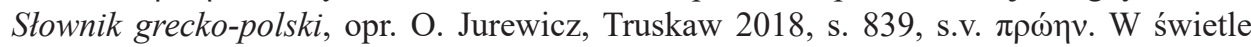
tego, co powiedziałem we wstępie do niniejszego przekładu (3.1 Data i okoliczności powstania), tłumaczę owo adverbium możliwie, jak mi się wydaje, niejednoznacznie i szeroko jako „ostatnio”.

82 Mt 18,23-35. Nowy Testament, a w paru zaledwie miejscach - zestawiając go z wersją Septuaginty - także Stary Testament, cytuję za: Biblia Tysiaclecia Online, Poznań 2003, w: https://biblia.deon.pl/ (dostęp: 06.05.2020).

83 I w tym miejscu należy odesłać czytelnika do wstępu do niniejszego przekładu (3.1 Data i okoliczności powstania), gdzie rzecz jest obszerniej przedstawiona. Tu wystarczy chyba tylko zaznaczyć, że możliwa jest dwojaka identyfikacja owego „wyjaśnienia” - odnosi się tu Jan albo do kazania De decem milium talentorum debitore (zob. przypis 55), albo do homilii dwudziestej z cyklu De statuis (zob. przypis 7).

84 Jan wskazuje tu temat swojej homilii: chce mówić o łagodności i delikatności. A ponieważ wcześniej omówił już tę postawę jakby teoretycznie, przedstawiając opowiadającą o niej przypowieść, tj. przypowieść o litościwym panu i jego nielitościwym dłużniku, teraz chce omówić ją jakby praktycznie, dając swoim słuchaczom jej przykład. Por. przypis 86.

85 Biorąc słowa Jana ściśle, za filozofię uznaje on tu postawę łagodności i delikatności, rozumiejąc natomiast jego słowa szerzej, co niewątpliwie jest wskazane, filozofią jest dlań tutaj chrześcijaństwo. W tym układzie łagodność i delikatność byłyby niejako streszczeniem całego chrześcijaństwa. Takiego sposobu mówienia o chrześcijaństwie, jako o filozofii i filozofowaniu, trzyma się Jan konsekwentnie w całej prezentowanej tu homilii. Pojmowanie chrześcijaństwa jako filozofii, i to najlepszej, najprawdziwszej ze wszystkich filozofii, właściwe jest wielu starożytnym autorom chrześcijańskim. Taki pogląd głosili i rozwijali m.in. Klemens Aleksandryjski, Justyn Męczennik, Orygenes czy Grzegorz z Nyssy. Zagadnienie jest niezwykle złożone, ma wiele wymiarów i aspektów. W konse- 
i przysposabiać do niej poprzez czyny ${ }^{86}$. Ponieważ zaś bardzo potrzeba nam tej cnoty, wybrawszy jednego ze świętych i postawiwszy go przed waszymi oczyma, na jego przykładzie będziemy was usilnie zachęcać, żebyście - zagrzewani i przez nas, i przez siebie nawzajem - niczym jakiś wzorcowy obraz naśladowali cnotę tego sprawiedliwego ${ }^{87}$. Mówiąc zaś o łagodności, kogo należy postawić jako przykład? Czy kogoś innego niż tego, który otrzymał świadectwo z góry i który był w związku z tym

kwencji istnieje na jego temat bardzo rozległa literatura. Zob. np. W. Löhr, Christianity as Philosophy: Problems and Perspectives of an Ancient Intellectual Project, „Vigiliae Christianae" 64/2 (2010) s. 160-188; K. Pawłowski, Spotkanie starożytnego chrześcijaństwa z filozofia grecka (w czasach Justyna Męczennika i Klemensa Aleksandryjskiego), „Collectanea Theologica” 86/2 (2016) s. 69-84; M. Kowalska, Chrześcijaństwo jako filozofia. Studium historyczno-literackie pism Orygenesa, Warszawa 2017; W. Jaeger, Wczesne chrześcijaństwo i grecka paideia, tł. K. Bielawski, Bydgoszcz 2002; H. Chadwick, Myśl wczesnochrześcijańska a tradycja klasyczna, tł. P. Siejkowski, Poznań 2000; E.R. Dodds, Pogaństwo i chrześcijaństwo w okresie niepokoju. Niektóre aspekty doświadczenia religijnego od Marka Aureliusza do Konstantyna Wielkiego, tł. J. Partyka, Kraków 2004; J.N.D. Kelly, Początki doktryny chrześcijańskiej, t1. E. Stanula, Warszawa 1988; J. Domański, Metamorfozy pojęcia filozofii, Warszawa 1996. Dość będzie tutaj za P. Hadotem ogólnie powiedzieć, iż można było w swoim czasie pojmować i prezentować chrześcijaństwo jako filozofię, ponieważ w swojej strukturze było ono podobne do wszystkich starożytnych filozofii, pośród których zrodziło się i funkcjonowało, to jest z jednej strony składała się na nie określona doktryna, powstała czy sformułowana wskutek czytania $\mathrm{i}$ interpretacji tekstu kanonicznego (Biblii), z drugiej zaś strony było ono konkretnym sposobem życia, konkretną życiową praktyką. Zob. P. Hadot, Czym jest filozofia starożytna?, tł. P. Domański, Warszawa 2000. Por. P. Hadot, Filozofia jako ćwiczenie duchowe, tł. P. Domański, Warszawa 2003.

86 Wskazując cel swojej homilii, Jan Chryzostom posługuje się tu dwoma czasownikami, mianowicie $\delta \_\delta ́ \sigma \kappa \omega$ oraz $\pi \alpha \iota \delta \varepsilon v ́ \omega$, oznaczającymi dlań dwie różne, aczkolwiek dopełniające się czynności wychowawcze. Pierwsza (nauczanie) odbywa się poprzez słowa ( $\delta \dot{\alpha} \tau \tilde{\omega} v \lambda o ́ \gamma \omega v)$, druga natomiast (kształcenie czy wdrażanie) dokonuje się poprzez

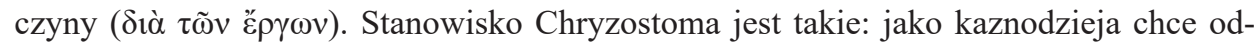
działać dydaktycznie na swoich słuchaczy z jednej strony słowem, z drugiej zaś czynem, tzn. wskazując im wzorcowy sposób postępowania. Tak pragnie naśladować Chryzostom

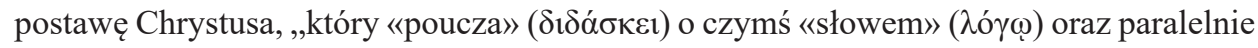
«pokazuje» ( $\pi \alpha 1 \delta \varepsilon v ́ \varepsilon \imath)$ to samo «za pomocą czynu» (๕̌ $\rho \gamma \omega)$ " - myśląc o dziele Jezusa, mówimy wszakże, zgodnie z tradycją teologiczną, o Jego słowach i czynach. Wydaje się, że mamy tu do czynienia z ideą w jakiejś mierze podobną tej, którą wyraża znane łacińskie porzekadło verba docent, exempla trahunt. Zob. E. Osek, Chryzostomowa terminologia wychowania, „Vox Patrum” 53-54 (2009) s. 378-379.

87 Omawia tu Chryzostom, tak to może ujmijmy, swoją metodę - sposób, w jaki zamierza oddziałać na słuchaczy. 
szczególnie podziwiany? „Znalazłem bowiem - mówi Pismo - Dawida, syna Jessego, męża według serca mojego"88. Ilekroć przecież Bóg przemawia, tylekroć oskarżycielom nie pozostaje żaden pretekst. Albowiem wyrok z góry jest bezstronny, jako że Bóg osądza, nie sprzyjając nikomu ani też nie mając do nikogo uprzedzeń: wyrokuje, kierując się samą tylko cnotą duszy. Podajemy tu zaś za przykład Dawida nie tylko z tego powodu, że otrzymał on świadectwo od Boga, ale także dlatego że jest jedną z postaci Starego Testamentu. Nie zdumiewa bowiem to, że po śmierci Chrystusa, po odpuszczeniu tylu grzechów, po wypełnieniu przykazań filozofii pojawia się ktoś wolny od gniewu, kto wrogom odpuszcza grzechy i kto ma litość dla zrozpaczonych. Lecz którym ze słuchaczy nie wstrząsa fakt, że w Starym Testamencie, kiedy Prawo pozwalało wyłupywać oko za oko i wybijać ząb za ząb ${ }^{89}$ i kiedy krzywdzony bronił się,

88 1Krl 13,14; por. Ps 88,21; Dz 13,22. Stary Testament cytuję za: Septuaginta, czyli Biblia Starego Testamentu wraz z ksiegami deuterokanonicznymi i apokryfami, th i opr. R. Popowski, Warszawa 2013. Trzeba tu zaznaczyć, iż Jan, jak zresztą wszyscy przedstawiciele teologicznej szkoły antiocheńskiej, posługiwał się Septuagintą w wersji syryjskiej, a więc Septuagintą zrecenzowaną przez Lucjana z Antiochii w oparciu o oryginał hebrajski oraz dostępne mu thumaczenia. Zob. na ten temat: Iohannis Chrysostomi De Davide et Saule homiliae tres, s. XI; H.B. Swete, An Introduction to the Old Testament in Greek, Cambridge 1902, s. 974-975. Z kolei o tej używanej przez Jana Septuagincie lucjańskiej trzeba wiedzieć, że była jedną z czterech, jak się dziś przyjmuje, zasadniczych wersji Septuaginty (obok egipskiej, palestyńskiej i konstantynopolitańskiej). Na temat wersji tekstu Septuaginty zob. np. J.W. Wevers, The Future of Septuagint Textual Studies, w: The Bible as Book: the Transmission of the Greek Text, red. S. McKendrick-O.A. O'Sullivan, Londyn 2003, s. 214-215. W ogóle o Septuagincie lucjańskiej, zob. G.F. Moore, The Antiochian Recension of the Septuagint, „The American Journal of Semitic Languages and Literatures" 29/1 (1912) s. 37-62; B.M. Metzger, Lucian and the Lucianic Recension of the Greek Bible, „New Testament Studies” 8/3 (1962) s. 189-203. W ten sposób staje się zrozumiałe - nie wspominając już o tym, iż starożytni kaznodzieje nie zwykli przytaczać fragmentów Pisma dosłownie, stosownie do potrzeby z pamięci je parafrazując - że tekst biblijny przywoływany przez Jana w thumaczonym tutaj kazaniu często różni się od dostępnego we współczesnych edycjach Septuaginty, a w konsekwencji różni się też od polskiego tekstu Septuaginty. Kiedy zatem taka sytuacja będzie miała miejsce, dosłowne brzmienie cytatu biblijnego w przekładzie R. Popowskiego podam w przypisie.

${ }^{89}$ Jan przywołuje tutaj formułę prawa talionu. Zasada ta pojawia się w Starym Testamencie trzy razy (Wj 21,24; Kpł 24,20; Pwt 19,21). Przywołuje ją także Jezus w kazaniu na Górze (Mt 5,38). Na temat prawa talionu, zob. np. G. Szamocki, „Oko za oko, zą za zab”. Formuta talionu w biblijnym prawie Izraela, „Studia Gdańskie” 17 (2004) s. 37-56; K. Koch, Um das Prinzip der Vergeltung in Religion und Recht des Alten Testaments, Darmstadt 1972; J.F. Davis, Lex talionis in early Judaism and the exhortation of Jesus in Matthew 5.38-42, London 2005; W.I. Miller, Eye for an Eye, Cambridge 2006. 
krzywdząc, zjawił się ktoś, kto przekraczał miarę przykazań i poprzedził filozofię apostolską? ${ }^{90}$ Bo czy komukolwiek spośród tych, którzy mu nie sprzyjali, odmówił on swego przebaczenia i usprawiedliwienia?

Abyśmy zatem dokładniej poznali cnotę Dawida, pozwólcie przytoczyć mi niedawno ${ }^{91}$ wygłoszoną mowę i opowiedzieć o dobrodziejstwach, którymi ów błogosławiony mąż obdarzył Saula. Nie bronić się bowiem przed wrogiem, który nas rani, to nie jest jeszcze nic dziwnego. Jednakże nie bronić się przed człowiekiem, który usiłuje zabić swego dobroczyńcę, pomimo doznanych odeń dobrodziejstw, pomimo tego, że raz, dwa razy i po wielokroć otrzymał od niego wielkie dobra, a więc nie bronić się przed takim człowiekiem, ale puścić go wolno, mimo że miało się go już schwytanego w swoich rękach, mimo że miało się władzę go zabić, i wyrwać go z zasadzki zastawionej nań przez innych, choć ten planował ponowny atak - czyż nie świadczy to o najwyższym stopniu filozofii?

2. Pozwólcie, że powiem krótko, jakie dobrodziejstwa, w jakim czasie i w jaki sposób Dawid wyświadczył Saulowi. Otóż wyniszczała niegdyś Żydów straszna wojna tak, że wszyscy trwożyli się i bali: nikt nie ośmielał się nawet wychylać, jako że całe państwo znajdowało się w skrajnym niebezpieczeństwie, a każdy miał śmierć przed oczyma i w każdej chwili spodziewał się umrzeć. Kiedy więc mężowie, którzy żyli, szli na pewną zagładę, wtedy Dawid, zostawiwszy owce, wstąpił w szeregi walczących, pomimo tego, że nieletniość i niedoświadczenie zwalniały go z podjęcia trudu wojennego, i w imieniu wszystkich stanął do pojedynku, i niespodzianie przywrócił ład. Choćby nawet i niczego on wówczas nie osiągnął, należało go nagrodzić za jego gorliwość i dobrą wolę. Gdyby wszak dokonał tego któryś z żołnierzy w wieku dojrzałym, nie byłoby w tym jeszcze nic dziwnego, wymagało bowiem tego prawo wojenne. Dawid natomiast nie zważał ani na to, że nie spoczywał na nim żaden obowiązek, ani nawet na to, że miał do pokonania wiele przeszkód, bo i brat go łajał, i król, widząc jego niedojrzałość i wielkość niebezpieczeństw, próbował go zatrzymać i kazał mu pozostać na miejscu, mówiąc doń: „Nie możesz pójść, bo ty jesteś jeszcze chłopięciem, a on to wojownik od swojej młodości" ${ }^{92}$. Jednakże

90 Jako człowieka, który przekroczył prawo talionu, przedstawia Jan Chryzostom Dawida także w swoim komentarzu do Ps 7,4.

91 Niestety, nie zdołałem ustalić, do którego swojego kazania odnosi się tu Złotousty. Por. Hill, Chrysostom's Homilies on David and Saul, s. 136, przyp. 8.

${ }_{92} 1 \mathrm{Krl} 17,33$. W polskim przekładzie Septuaginty wers ten brzmi tak: „Nie możesz pójść do tego obcoplemieńca, aby z nim walczyć, bo ty jesteś jeszcze chłopięciem, a on to wojownik od swojej młodości”. 
Dawid, niczym się nie wymawiając, z własnej woli, rozpalony zapałem boskim oraz miłością do ojczyzny, bez strachu ruszył na barbarzyńców, jakby widząc przed sobą raczej owce niż ludzi i jakby chcąc pędzić raczej psy niż oddział wrogów. Wtedy też okazał on taką troskę o króla, że podniósł go, gdy tamten leżał załamany w obawie przed przegraną. Zanim bowiem wsparł króla swoimi czynami, najpierw pocieszał go słowami i przekonywał, aby nie podupadał na duchu i miał niezachwianą nadzieję na przyszłość, tak mówiąc: „Niech serce mojego pana nie dręczy się nim. Twój sługa pójdzie i będzie walczył z tym obcoplemieńcem"93.

Powiedz mi, czyż mało to, że Dawid ofiarował swoje życie i rzucił się w sam środek nieprzyjaciół, aby uratować wszystkich rodaków, choć nie miał wobec nich żadnego obowiązku, bo nigdy niczego dobrego od nich nie zaznał? Czyż po tych wydarzeniach nie trzeba było zamianować go ich władcą i obwołać jedynym wybawcą państwa, dlatego że dzięki łasce Boga zachował granice królestwa, terytorium miast i życie ich wszystkich? Jakie dobrodziejstwo byłoby większe od tego? Wyświadczył przecież Dawid owo dobro nie dla zysku, sławy czy władzy, lecz z uwagi na życie Saula; i z samych bram śmierci go zawrócił, tak że - patrząc na to, co zaszło, po ludzku - dzięki Dawidowi król nadal żył i cieszył się władzą. A jak Saul odwdzięczył się potem Dawidowi? Gdyby ktokolwiek, kto znalazłby się na miejscu króla, zmiarkował wielkość czynu Dawida, to choćby i zdjął koronę z własnej głowy i włożył ją na głowę Dawida, nie oddałby mu jeszcze sprawiedliwości i $\mathrm{w}$ dalszym ciągu pozostawałby jego dłużnikiem. Tymczasem zaś Saul, zawdzięczając Dawidowi zarówno życie, jak i władzę królewską, zwlekał z przekazaniem mu władzy.

Zobaczmy przeto, czym się mu odpłacił. Jak odwdzięczył się Saul Dawidowi? Odtąd był wobec niego podejrzliwy i od tego dnia patrzył na niego złym okiem. Z jakiego powodu? I dlaczego? Trzeba stwierdzić, że powodem była tu zazdrość. A cokolwiek zechciałby ktoś rzec w obronie Saula, nie powiedziałby nic sprawiedliwego. Bo czy istniała jakakolwiek podstawa do żywienia zazdrości wobec człowieka, który uratował mu życie i życie mu darował? Spójrzmy jednak na przyczynę tej wrogości, abyście pojęli, że stanowiło ją nie tyle zwycięstwo, ile to, że z powodu owego zwycięstwa Dawid był honorowany przez lud - stąd to Saul stał się podejrzliwy wobec Dawida i wrogo do niego nastawiony. Jaka więc była przyczyna tej wrogości? Kiedy wziął odciętą głowę barbarzyńcy i wracał z łupem - czytamy w Piśmie - „wychodziły na powitanie Dawida tancerki z bębenkami,

$93 \quad 1 \mathrm{Krl} 17,32$. 
a kobiety śpiewały, mówiąc: «Saul rozgromił tysiące, a Dawid - dziesiątki tysięcy». I rozgniewał się Saul, i odtąd, od tego dnia patrzył podejrzliwie na Dawida"94. Z jakiego więc powodu, powiedz mi, gniewał się Saul na Dawida? Choćby nawet kobiety wyśpiewywały swoje pochwały niesłusznie, nie należało traktować Dawida tak wrogo. Wręcz przeciwnie, Saul nie powinien był podejrzewać Dawida o złe zamiary, gdyż mógł się przekonać o jego życzliwości wobec siebie, gdy Dawid nieprzymuszony, z własnej woli naraził się na wielkie niebezpieczeństwo. Tymczasem owe pochwały kobiet były uzasadnione, co więcej, rzec należy - co może was zadziwi że kobiety schlebiały w nich bardziej Saulowi aniżeli Dawidowi. Dlatego też Saul winien był raczej kochać Dawida - za to, że dzięki Dawidowi kobiety powiedziały o nim samym, iż powalił tysiące. Czemu więc Saul się oburza, że o Dawidzie powiedziano, iż pokonał dziesiątki tysięcy? Gdyby cokolwiek zdziałał w tej wojnie i odniósł choćby najmniejsze zwycięstwo, wtedy może słusznie by powiedziano, że Saul pobił tysiące, a Dawid dziesiątki tysięcy. Skoro zaś Saul każdego dnia siedział w domu, drżąc ze strachu i czekając na śmierć, podczas gdy Dawid dokonywał wszystkiego, to czyż nie było niedorzecznością, iż ten, który unikał jakichkolwiek niebezpieczeństw, oburzył się, nie otrzymawszy większej pochwały? Jeśli miałby się tu już ktoś gniewać, gniewać powinien się Dawid, bo choć sam wszystkiego dokonał, otrzymał pochwałę tylko za część swoich zwycięstw.

3. Na ten temat nie chcę się jednak rozwodzić, pragnę bowiem skupić się na sprawie następującej. Otóż przyjmijmy, że kobiety postąpiły źle oraz że oskarżenia i skarga Saula są słuszne - lecz co to ma wspólnego z Dawidem? Nie on przecież skomponował tym kobietom pieśni ani nie on nakłonił je do tego, żeby śpiewały, ani nie on zdecydował o takim, a nie innym sposobie pochwały. Jeśli przeto trzeba było się oburzać, to należało oburzyć się na owe kobiety, nie zaś na jedynego dobroczyńcę państwa, godnego tysięcy wieńców. Tymczasem Saul, darując kobietom, cały swój gniew skierował na Dawida. Gdyby ów mąż błogosławiony, zepsuty pochwałą niewieścią, stał się wrogi i arogancki względem króla lub obraził jego godność królewską, wtedy nienawiść Saula miałaby może jakąś podstawę. Skoro jednakowoż Dawid, wysłuchawszy śpiewów kobiet, stał się jeszcze łagodniejszy i jeszcze spokojniejszy i stale dbał o to, aby zacho-

94 1Krl 18,6-9: „Z wszystkich miast Izraela wychodziły na powitanie Dawida tancerki z bębenkami, w radosnym nastroju i z kymbalonami, a kobiety śpiewały, mówiąc: «Saul rozgromił tysiące, a Dawid dziesiątki tysięcy». Wymowa tych słów wydawała się oczom Saula nieżyczliwa. Mówił: «Dawidowi przyznały dziesiątki tysięcy, a nie tysiące». Od tego dnia Saul patrzył podejrzliwie na Dawida”. 
wywać się wobec Saula tak, jak przystało na poddanego, to czyż Saul miał jakiś słuszny powód do zawiści? Ilekroć nagrodzony nadyma się wobec przełożonego i ciągle pyszni się przed nim okazanymi sobie względami, tylekroć zawiść ma jakąś rację bytu. Skoro jednak Dawid nieustannie okazywał królowi szacunek, a wydaje się nawet, że jeszcze gorliwiej mu we wszystkim służył, to jaką przyczynę mogła mieć Saulowa zawiść? A ponieważ w zaistniałej sytuacji Dawid postępował tak właśnie, Saul powinien był jeszcze bardziej go pokochać - za to, że choć miał doskonałą okazję do przejęcia władzy, zachował właściwą sobie skromność. Dlatego że ani wcześniejsze, ani późniejsze wydarzenia, które były o wiele donioślejsze, nie rozzuchwaliły Dawida.

Jakie zaś były to wydarzenia? ${ }^{95}$ Mówi Pismo: „We wszystkich swoich poczynaniach Dawid wykazywał rozwagę, bo Pan był z nim. I cały Izrael i Juda kochali Dawida, bo to on brał udział w wyprawach, stojąc na czele ludu. A Melchol, córka Saula, i cały Izrael kochali go. Saul natomiast mawiał do wszystkich swoich dworzan, że trzeba zabić Dawida. A imię Dawida stawało się coraz sławniejsze. I Jonatan, syn Saula, bardzo kochał Dawida"96. Tak więc Dawid, pozyskawszy każdego człowieka oraz cały dom króla i zwyciężywszy we wszystkich bojach, a nigdy żadnego nie przegrawszy, i otrzymawszy nagrody za wszystkie wyświadczone przez siebie dobrodziejstwa, nie zatracił się jednak i nie zapragnął władzy ani też nie bronił się przed wrogością Saula, lecz trwał względem niego w wielkoduszności, doprowadzając w imieniu króla do szczęśliwego zakończenia wojny. Któż tedy byłby na tyle nieokrzesany, iżby w takim położeniu nie dać się przekonać, by porzucić złość i odstąpić od nienawiści? Lecz nic nie zdołało skłonić do tego owego prymitywa i prostaka, Saula, który zupełnie zaślepiony i owładnięty zawiścią usiłował zabić Dawida.

95 Warto zauważyć, że opowiadając o kolejnych owych wydarzeniach, Jan przedstawia je w sposób pełny emocji i napięcia: jakby przechodzi od, jeśli można tak to ująć, najlżejszych przewin Saula wobec Dawida do jego niesprawiedliwości najcięższych.

$961 \mathrm{Krl} 18,14.16 .20$ oraz 19,1: ,We wszystkich swoich poczynaniach Dawid wykazywał rozwagę, bo Pan był z nim. Cały Izrael i Juda lubili Dawida, bo to on brał udział w wyprawach, stojąc na czele ludu. W Dawidzie zakochała się Melchol, córka Saula. Saul namawiał Jonathana, swojego syna, a także wszystkich swoich dworzan, że trzeba zabić Dawida. Jonathan jednak, syn Saula, bardzo lubił Dawida”. Por. z tłumaczeniem Biblii Tysiąclecia 1Sm 18,14.16.20 oraz 19,1: „Dawid we wszystkich przedsięwzięciach miał powodzenie: Pan był z nim. [...] Cały Izrael i Juda miłowali Dawida, wyprawiał się bowiem i powracał na ich oczach. Ale Mikal, córka Saula, pokochała Dawida. Saul namawiał syna swego Jonatana i wszystkie sługi swoje, by zabili Dawida. Jonatan jednak bardzo upodobał sobie Dawida". 
A ten - co jest jeszcze bardziej godne podziwu - cóż czynił? Grał swymi palcami na strunach ${ }^{97}$, aby w ten sposób uśmierzyć szaleństwo Saula. Czytamy bowiem w Piśmie: „Dawid zaczął grać swą ręką na strunach, tak jak to robił codziennie. A w ręku Saula była włócznia. Saul podniósł tę włócznię i rzekł: «Trafię w Dawida?» Lecz Dawid dwukrotnie uchylił się przed pociskiem"98. Czyż mogło spotkać Dawida jeszcze coś gorszego? Oto po odparciu wrogów, kiedy państwo zostało już odbudowane i kiedy wszyscy składali Bogu ofiarę dziękczynną za zwycięstwo, Saul próbował zgładzić grającego na strunach Dawida, dobrodzieja wszystkich i wybawiciela, sprawcę wszelkich dóbr, a żadne uczynione przez Dawida dobro nie było w stanie pohamować owego obłąkańca - i raz więc, i drugi rzucił oszczepem, żeby Dawida zabić. Tak to wynagrodził Saul Dawida za to, że naraził on swoje życie. A dopuszczał się tego Saul po wielokroć, nie zaś tylko jednego dnia. Ale nawet i po wszystkich tych zajściach święty Dawid troszczył się o sprawy Saula, dla zapewnienia mu bezpieczeństwa samego siebie wystawiając na niebezpieczeństwa, biorąc udział w każdej wojnie i podejmując wszelkie ryzyko, aby tylko ocalić swojego niedoszłego mordercę - $\mathrm{i}$ ani słowami, ani swoimi czynami nie rozjuszał onej dzikiej bestii, lecz wszystkiego się słuchał i we wszystkim był jej poddany. I nie otrzymywał wynagrodzenia przysługującego mu za zwycięstwa, a pozbawiony zapłaty za podejmowane trudy nigdy nawet słowem nie poskarżył się czy to żołnierzom, czy królowi - albowiem nie czynił Dawid tego wszystkiego dla ludzkiej nagrody, ale spodziewając się odpłaty z wysoka. A godne podziwu jest nie tylko, że nie żądał on zapłaty, ale także i to, iż z największą pokorą odmówił przyjęcia tego, co mu ofiarowano. Skoro bowiem Saul, bardzo przebiegle usiłując wykorzystać ku temu rozmaite okazje, nie zdołał doprowadzić do śmierci Dawida, złożył mu propozycję małżeństwa

$97 \Psi \alpha ́ \lambda \lambda \omega$ - idąc za R. Popowskim (por. 1Krl 19,9) - przekładam tu jako 'grać na strunach' czy 'grać na instrumencie strunowym'. Analiza zakresu semantycznego tego czasownika nie pozawala bowiem rozstrzygnąć, o jaki instrument chodzi. $\Psi \alpha ́ \lambda \lambda \omega$ znaczy m.in. 'szarpać, trącać coś, pociągać, wypuszczać, naprężać i puszczać, brząkać, uderzać w struny', później także 'śpiewać przy wtórze harfy', w stronie pasywnej czasownik ten znaczy 'być trącanym, uderzanym, kazać przygrywać na lirze, harfie, słuchać gry'. Por.

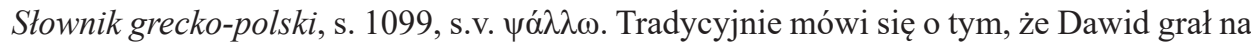
harfie, lutni albo cytrze.

98 1Krl 18,10-11. W całości miejsce to brzmi tak: „Następnego dnia Saula opanował szkodliwy duch, posłany przez Boga. Prorokował w swoim domu, dlatego Dawid zaczął grać swą ręką na strunach, tak jak to robił codziennie. A w ręku Saula była włócznia. Saul podniósł tę włócznię i rzekł: «Trafię w Dawida czy w ścianę?» Lecz Dawid dwukrotnie uchylił się przed pociskiem". 
i obmyślił nowy zupełnie sposób daru ślubnego i zapłaty za pannę młodą99. Rzecze wszak Pismo: „Król nie chce żadnego daru, lecz tylko sto napletków obcoplemieńców, gdyż pragnie ukarać wrogów króla"100. Saul natomiast przemówił następującymi słowy: „Zabij dla mnie stu mężów, a to twój ślubny dar dla mnie"101. Powiedział zaś tak, ponieważ pod pozorem propozycji małżeństwa chciał posłać Dawida na pewną śmierć.

4. Jednakże Dawid, zapatrując się na całą sprawę podług swojej prostolinijności, odmawiał zawarcia oferowanego mu małżeństwa - nie bynajmniej ze względu na niebezpieczeństwo ani też nie ze strachu przed wrogiem, ale dlatego że uważał się za niegodnego bycia związanym poprzez relację rodzinną z Saulem. Tak tedy przemawiał do sług Saula: „Czy zostać zięciem króla wydaje się wam czymś błahym? Ja jestem człowiekiem biednym i bez żadnego znaczenia"102. A to przecież bezspornie jako nagroda i zapłata należało mu się za jego znoje. Lecz miał serce tak skromne, iż sądził, że po tylu znakomitych dokonaniach i tak wspaniałym zwycięstwie nie zasługuje na taką łaskę, którą mu już nawet przyobiecano, i trwał w tym przekonaniu, pomimo iż $\mathrm{w}$ dalszym ciągu zamierzał podejmować niebezpieczne wyzwania. A kiedy ujarzmił już Dawid wrogów i pojął córkę króla za żonę, to - mówi Pismo - wszystko zaczęło się od nowa: „Dawid grał swymi palcami na strunach. Wtedy Saul próbował ugodzić Dawida włócz-

99 Na kartach Starego Testamentu mówi się o tego rodzaju darze (hebr. mohar) tylko trzy razy (Rdz 34,12; Wj 22,16 oraz właśnie w interesującym nas miejscu - idę tu za Biblią Tysiąclecia - 1Sm 18,25), choć dar ten był w kulturze starożytnego Izraela niezwykle istotny: wszystko wskazuje na to, że od jego złożenia zależała ważność małżeństwa. Rodzaj - bo mógł on być albo pieniężny, albo naturalny, albo odpracowany - i wielkość czy wysokość tego daru określał każdorazowo ojciec lub opiekun dziewczyny, o której rękę starał się młodzieniec, zanim jeszcze dziewczyna została mu przyobiecana. Kiedy chłopak złożył mohar, dziewczyna trafiała do niego w charakterze jakby wynagrodzenia, chociaż rzeczywistości tej nigdy nie traktowano jako wymiany handlowej, pomimo że do wymiany handlowej jest przecież bardzo podobna. Z jednej strony instytucja moharu była swoistym rodzajem odszkodowania, jakie pan młody wypłacał rodzinie swojej wybranki za straty, jakie ona poniesie w związku z odejściem córki. Z drugiej strony natomiast mohar miał funkcję prestiżową, tym większą, z im bogatszej i bardziej wpływowej rodziny pochodził mężczyzna. Zob. na ten temat m.in. B.W. Matysiak, Matżeństwo i rodzina w kulturze starożytnego Izraela, „Studia Elbląskie” 13 (2012) s. 133-151; W. Plautz, Die Form der Eheschließung im Alten Testament, „Zeitschrift für die Alttestamentliche Wissenschaft" 76 (1964) s. 298-318; T.M. Lemos, Marriage Gifts and Social Change in Ancient Palestine: 1200 BCE to 200 CE, Cambridge 2010.

$1001 \mathrm{Krl} 18,25$.

101 Por. $1 \mathrm{Krl} 18,25$.

$1021 \mathrm{Krl} 18,23$. 
nią. I rzucił włócznię. Lecz Dawid odskoczył od Saula, tak że włócznia utkwiła w ścianie"103. Czyż takie postępowanie Saula nie poruszyłoby aż do trzewi każdego, nawet i człowieka o najbardziej filozoficznym usposobieniu? I czyż takie wypadki nie skłoniłyby każdego do tego, żeby w trosce o własne bezpieczeństwo zabić tego, który nosi się ze złymi zamiarami? Czyn taki nie byłby przecież morderstwem - co więcej, nie byłby on nawet żadnym wykroczeniem przeciw Prawu. Prawo nakazywało bowiem wyłupić oko za oko. Choćby więc Dawid zabił Saula, to i tak za trzy zabójstwa - i to zabójstwa niemające żadnego słusznego powodu - odpłaciłby się mu jednym zabójstwem ${ }^{104}$. Nie tak jednakże postąpił Dawid. Zamiast stać się królobójcą, opuścił dom ojcowski i obrał sobie wygnanie, tułaczkę, włóczęgostwo i życie w takiej nędzy, iż jadał tylko tyle, ile było konieczne. Wszelako nie zastanawiał się on nad tym, jak by mógł zemścić się na Saulu, ale nad tym, jak by mógł mu pomóc. Dlatego też usunął się sprzed oczu swego wroga - ażeby umniejszyć jego pychę i przygasić buchający w nim płomień zazdrości. „Lepiej dla mnie - jakby rzekł Dawid - cierpieć i znosić niezliczone mnóstwo okropności niż być oddzielonym od Boga z powodu niesprawiedliwości i zabójstwa".

103 Krl 19,9-10. Wersy te brzmią dokładnie tak: „Złośliwy duch, posłany przez Boga, opanował kolejny raz Saula, kiedy spoczywał na łożu z włócznią w ręce, a Dawid grał swymi palcami na strunach. Wtedy Saul próbował ugodzić Dawida włócznią. Dawid odskoczył od Saula, tak że włócznia utkwiła w ścianie. Dawid uciekł i tak ocalał”.

$104 \mathrm{~W}$ niniejszej homilii (to jeden z jej zasadniczych wątków) Chryzostom ukazuje Dawida jako człowieka, który przekroczył zasady starotestamentalnego Prawa. W tym miejscu Jan podkreśla, jak dalece poprzez swoją postawę odstąpił Dawid od tego, co mówiły przepisy Tory: gdyby bowiem nawet zabił Saula - powiada tu Złotousty - to odpłaciłby mu się nie tym samym, ale czymś dużo mniejszym za to, czego z jego ręki był zaznał. Warto tę myśl Jana widzieć w kontekście antycznego rozumienia proporcjonalności jako jednej z podstawowych zasad sprawiedliwości. F. Wieacker stwierdza, że w związku z zasadą proporcjonalności w antycznych Grecji i Rzymie trzeba mieć na uwadze trzy kwestie. Po pierwsze, chodziło w owej zasadzie nie o zaspokojenie osobistej potrzeby zemsty, ale o podporządkowanie się regułom gwarantującym porządek publiczny. Po drugie, filozofie grecka i rzymska wymagały, aby zarówno między prawami a obowiązkami, jak i między wyrządzonym złem a wynagrodzeniem za nie była proporcja. Po trzecie, starożytni filozofowie greccy i rzymscy proporcjonalność uznawali za podstawowe narzędzie zapewniające osiągnięcie społecznego ładu. Zob. F. Wieacker, Geschichtliche Wurzeln des Prinzips der verhältnismäßigen Rechtsanwendung, w: Festschrift für Fischer, ed. M. Lutter - W. Stimpel - H. Wiedemann, Berlin - New York 1979, s. 874-880; M. Cohen-Eliya - I. Porat, Proportionality and Constitutional Culture, Cambridge 2013, s. 24. 
Nie tylko słuchajmy tych słów Dawidowych, lecz idźmy za nimi i naśladujmy wszystko, co Dawid robił i co znosił, żebyśmy zdołali uwolnić naszych wrogów od ich nienawiści wobec nas. I nie dochodźmy tego, czy słusznie, czy niesłusznie oni nas nienawidzą, lecz o to jedno tylko zabiegajmy, żeby już dłużej nas nie nienawidzili. Bo i lekarz bada, w jaki sposób mógłby uwolnić chorego od jego choroby, a nie to, czy chory zapadł na swoją chorobę słusznie czy niesłusznie. A zatem i ty bądź lekarzem tego, który ci zazdrości. I o to jedno tylko się staraj, abyś usunął odeń jego chorobę. Tym zaś, co błogosławiony Dawid uczynił dla Saula, było to, iż wybrał ubóstwo zamiast bogactwa, wygnanie zamiast życia w ojczyźnie, trudy i niebezpieczeństwa zamiast zbytku i beztroski, niekończącą się tułaczkę zamiast siedzenia w domu - ażeby uwolnić króla od nienawiści i wrogości względem siebie. Aczkolwiek nic to nie pomogło Saulowi, bo dalej postępował jak dotąd i chodził w te i z powrotem, szukając Dawida, który nie wyrządził mu żadnego zła, lecz przeciwnie - sam został przez niego głęboko skrzywdzony, a mimo to za doznane odeń krzywdy odpłacał się mu niezmierzonym dobrem. Aż w końcu niczego nieświadomy Saul wpadł w sidła zastawione na niego przez Dawida. Rzecze wszak Pismo: „Była tam jaskinia. Saul wszedł do niej, aby odpocząćc ${ }^{105}$. Tymczasem Dawid

105 W Septuagincie czytamy: „Saul wszedł do niej, aby sobie ulżyć”. Przez to rozumiemy, że Saul wszedł do jaskini za potrzebą. Biblia Tysiąclecia pozostawia w tym miejscu idiom hebrajski: „Była tam jaskinia, do której wszedł, by okryć sobie nogi” (1 Sm 24,4). Uważa się, że jest to wschodni eufemizm na oznaczenie czynności spełniania potrzeb fizjologicznych (miejsce paralelne - podaję je tu za Biblią Tysiąclecia - to Sdz 3,24: „Po jego odejściu nadeszli słudzy i spostrzegli, że drzwi letniej komnaty są zaryglowane. Mówili więc do siebie: «Z pewnością chce okryć sobie nogi w letniej komnacie»"). Jednak z dalszej części niniejszego kazania, a także z dwóch pozostałych kazań z cyklu De Davide et Saule, wynika, że chodzi tu nie o takie szczegółowe znaczenie czasownika $\pi \alpha \rho \alpha \sigma \kappa \varepsilon v \alpha ́ \zeta \omega$, ale o jego znaczenie ogólniejsze: przygotować się, a w tym wypadku przygotować się poprzez odpoczynek, drzemkę, sen. Por. Słownik grecko-polski, s. 727, s.v. $\pi \alpha \rho \alpha \sigma \kappa \varepsilon v \alpha ́ \zeta \omega$. Ponadto jako argument za takim właśnie tłumaczeniem odnośnego miejsca można wskazać fakt następujący. Otóż Jan Chryzostom żył i działał w środowisku syryjskim, to jest w syryjskiej Antiochii drugiej połowy IV wieku. Tymczasem Peszitta - a więc, jak się ją krótko określa, syryjski odpowiednik łacińskiej Wulgaty - z którą w jakieś mierze musiał się zetknąć, jeśli nie bezpośrednio, to przynajmniej pośrednio, interesujący nas tu wers oddaje w taki sposób: „Saul wszedł do jaskini i tam spał”. Wyznacza zatem to thumaczenie syryjskie inną tradycję rozumienia eufemistycznego idiomu hebrajskiego. Zob. Ancient Texts and Modern Readers: Studies in Ancient Hebrew Linguistics and Bible Translation, red. G.R. Kotzé - Ch.S. Locatell - J.A. Messarra, Leiden - Boston 2019, s. 220. Dodajmy, iż nie wyklucza się dziś, że Jan Chryzostom mógł w jakieś mierze używać Peszitty. Zob. S.-I. Lee, Jesus and Gospel Traditions in Bilingual Context: A Study 
i jego ludzie siedzieli w głębi tej właśnie jaskini. Ludzie Dawida rzekli mu: «Oto chwila, o której Pan mówił ci, zapowiadając, że wyda w twoje ręce twojego wroga; że będziesz mógł uczynić z nim wszystko, co twoim oczom wyda się dobre». Wtedy Dawid podniósł się i tylko odciął po cichu frędzel ${ }^{106}$ płaszcza Saula. Potem jednak zaczęło serce wyrzucać Dawidowi, że odciął frędzel jego płaszcza. Odezwał się więc Dawid do swoich ludzi: «Nie powinienem jednak wbrew Panu czynić takiej rzeczy mojemu panu, który jest namaszczony przez Pana. Nie mogę podnieść swej ręki na niego, bo przecież jest on pomazańcem Pana!»" "107.

Czy widzisz te założone sidła, złowioną zwierzynę, stojącego przy niej myśliwego i wszystkich tych, którzy nakłaniają go do tego, aby zanurzył swój miecz w piersi wroga? ${ }^{108}$ Nuże, spójrz na tę filozofię, spójrz na owe zapasy, na zwycięstwo i na wygraną! ${ }^{109}$ Owa bowiem jaskinia była areną,

in the Interdirectionality of Language, Berlin - Boston 2012, s. 167. Można jeszcze zaznaczyć w tym miejscu, że nie wiemy, jakie słowo użyte zostało w interesującym nas tu wersie w Chryzostomowej Septuagincie lucjańskiej, niewykluczone bowiem, że i tam mowa była o drzemce czy po prostu śnie. Parę słów o Septuagincie w redakcji Lucjana, zob. przypis 88 .

106 W Septuagincie czytamy: „Wtedy Dawid podniósł się i tylko odciął po cichu połę płaszcza Saula. Potem jednak zaczęło serce wyrzucać Dawidowi, że odciął połę jego płaszcza". Tak samo zresztą i Biblia Tysiąclecia podaje, że Dawid odciął połę płaszcza Dawida (1Sm 24,5-6). Wszelako wydaje się, że poła to mimo wszystko dość jednak znaczny fragment ubrania, którego odcięcie Saul z pewnością bardzo łatwo by zauważył. W słowniku języka polskiego czytamy, iż poła to „dolny fragment jednej z dwóch części ubioru rozpinającego się z przodu". Stownik języka polskiego, red. W. Doroszewski, Warszawa 1958-1969, s.v. poła, w: https://sjp.pwn.pl/sjp/pola;2504085.html (dostęp: 08.06.2020). Można natomiast przez słowo $\tau$ ò $\pi \tau \varepsilon \rho u ́ \gamma$ iov rozumieć, jak podaje F. Montanari, frędzel przy ubraniu lub uzbrojeniu. Zob. F. Montanari, The Brill Dictionary of Ancient Greek,

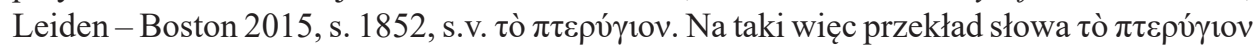
w odnośnym miejscu się decyduję, będąc przekonanym, iż takie rozwiązanie translatorskie przyczynia się do uwyraźnienia sensu i wymowy tak zajmującego nas tu fragmentu biblijnego, jak i tego, co zaszło między Dawidem a Saulem w jaskini.

107 Krl 24,4-7.

108 Wydaje się, że wraz z tym pytaniem rozpoczyna się punkt kulminacyjny całej homilii.

109 Tak filozofia, jak zapasy, zwycięstwo i wygrana to metafory chrześcijaństwa. Na temat chrześcijaństwa jako filozofii, zob. przypis 85. Z kolei przyrównanie chrześcijaństwa z jednej strony do zapasów, z drugiej zaś - już do zwycięstwa i wygranej w tych zapasach ma swoje korzenie bodaj w myśli świętego Pawła: „W dobrych zawodach wystąpiłem, bieg ukończyłem, wiary ustrzegłem. Na ostatek odłożono dla mnie wieniec sprawiedliwości, który mi w owym dniu odda Pan, sprawiedliwy Sędzia, a nie tylko mnie, ale i wszystkim, którzy umiłowali pojawienie się Jego" (2Tm 4,7-8). Zob. w tym kontekście np. T. Gacia, Metaforyka agonistyczna w literaturze łacińskiej chrześcijańskiego antyku, 
na której stoczyła się jakaś przedziwna i nieprawdopodobna walka. Wszak Dawid był tam zapaśnikiem, duch jego walczył tam na pięści, Saul leżał tam jako nagroda, Bóg zaś w tamtych zawodach sędziował. A toczył Dawid ów bój w jaskini nie tylko z samym sobą, lecz także z otaczającymi go żołnierzami. Bo skoro chciał filozofować i zamierzał oszczędzić swojego ciemiężyciela, musiał obawiać się tego, że jego żołnierze nie okażą mu tego samego i że uderzą go w jaskini wraz z Saulem, uznawszy go za zdrajcę i wybawiciela ich wspólnego wroga. A to dlatego, że było prawdopodobne, iż każdy z towarzyszy Dawidowych w swoim rozgoryczeniu powie: „Staliśmy się tułaczami i zbiegami, utraciliśmy dom, ojczyznę i wszystko inne i dzieliliśmy z tobą wszystkie trudy, a ty, dzierżąc w swoich rękach przyczynę całego tego zła, chcesz ją wypuścić, abyśmy już nigdy od tego zła nie odetchnęli, i troszcząc się o swojego wroga, uratujesz go, zdradziwszy swoich przyjaciół? Gdzież tu sprawiedliwość? A jeśli masz już za nic swoje bezpieczeństwo, to oszczędź przynajmniej nasze życie! Czyż nie wzburza cię to, co się stało? Czy nie pamiętasz już żadnego z nieszczęść, jakie sprowadził na nas Saul? Przez wzgląd na przyszłość go zabij, żebyśmy nie musieli cierpieć jeszcze większych i straszniejszych nieszczęść!"”. Wprawdzie nie odezwali się żołnierze do Dawida w takich słowach, ale na pewno tak pomyśleli, a może nawet znacznie gorzej.

5. Jednakże sprawiedliwy Dawid nic z tego nie wziął pod rozwagę, ale na to jedno tylko baczył, jak by mógł zdobyć wieniec łagodności i w jaki jeszcze nowy sposób mógłby uprawiać swoją filozofię. Bo nie byłoby to aż tak niebywałe, gdyby oszczędził swojego oprawcę, będąc z nim sam na sam - lecz on uczynił to w obecności własnej drużyny! Toż owa obecność żołnierzy zdwoiła trudność, przed jaką stanął tu Dawid ze swoją filozofią! Wszak często zdarza się przecież, że postanawiamy zaniechać gniewu i przebaczyć temu, kto wobec nas zawinił, ale potem przychodzą do nas judziciele i nagabują nas do wzięcia odwetu, i pod wpływem ich słów zmieniamy wcześniej podjętą decyzję. Lecz nie tak postąpił ów mąż błogosławiony, ale nawet namawiany i nakłaniany do mordu trwał przy tym, co raz powziął. A nie wyłącznie to jedno jest godne podziwu, że ani nie uległ poduszczeniom towarzyszy, ani się ich nie przestraszył, lecz także i to, że nakłonił ich do filozofowania według własnego sposobu. Wielka

Kielce 2007; J. Kochel, Pedagogiczna wartość sportu w nauczaniu Jana Chryzostoma, w: http:/www.ssb24.pl/warto_przeczytac,22 (dostęp: 08.06.2020); P. Kasiłowski, Metafory sportowe w Listach Pawta, w: Salezjanie a sport, red. Z. Dziubiński, Warszawa 1998, s. 34-42; D. Słapek, Sport i widowiska w świecie antycznym, Kraków - Warszawa 2010; J. Swaddling, Starożytne igrzyska olimpijskie, tł. J. Lang, Poznań 2004. 
bowiem to rzecz panować nad swoimi namiętnościami, jednakże rzeczą o wiele większą jest pozyskać także innych dla swojego stanowiska - i to innych, którzy nie należą do ludzi łagodnych i opanowanych, ale są żołnierzami zaprawionymi w walce, $\mathrm{z}$ uwagi na ogrom podejmowanych trudów pogrążonymi w rozpaczy, wyczekującymi choćby krótkiego odpocznienia, którzy doskonale wiedzą, że jeśli w tej oto chwili ich wróg zostanie zgładzony, to skończą się wszystkie ich nieszczęścia, a nie tylko ich nieszczęścia się skończą, lecz również zdobędą nieprzeliczone dobra. Gdyby wszelako Saul został zabity, przed będącymi w jaskini stanęłaby otworem droga wiodąca do przejęcia władzy w królestwie. A jednak kiedy obecni przy Dawidzie mężowie naciskali na niego, on, szlachetny, wszystkich ich opanował i zdołał przekonać ich do tego, by oszczędzili wroga.

Warto zaś przysłuchać się temu, co radzili żołnierze Dawidowi, a to dlatego, iż niegodziwość ich zachęty jeszcze wyraźniej pokazuje niezmienność i stałość postawy naszego sprawiedliwego. Żołnierze nie powiedzieli bowiem do Dawida: „Oto ten, który wyrządził ci bardzo wiele zła, który pragnął twej śmierci, który miażdżył nas straszliwymi okrucieństwami”. Lecz skoro spostrzegli, że nie zważał on na to wszystko i że ani słowem nie poskarżył się na krzywdy, jakie go spotkały, przywołali mu wyrok z góry, mówiąc: „Bóg go wydał tobie"110, aby Dawid, uszanowawszy to boskie zrządzenie, niezwłocznie dokonał mordu. „Czy nie pomścisz teraz samego siebie?” - jakby go pytali. „Służysz przecież i oddany jesteś Bogu, i wypełniasz Jego rozkazy!”. A im dłużej tak mówili, tym bardziej Dawid chciał go oszczędzić. Wiedział bowiem, że za sprawą Opatrzności mając przed sobą bezbronnego Saula, swoją chwałę może uczynić jeszcze większą. I ty zatem, kiedy twój wróg wpadnie ci w ręce, uznaj to nie za okazję do wzięcia na nim odwetu, lecz za okoliczność do zbawienia się. Skoro zaś zbawienie mamy na uwadze, pamiętajmy, że wrogów trzeba nam oszczędzać zwłaszcza wtedy, gdy cały ich los zależy wyłączne od nas. Acz mógłby tu ktoś rzec: „No i cóż to wielkiego i zadziwiającego w tym, że ten, który został królem, lituje się nad swoim nieprzyjacielem?”. I tak zapytać byłoby tu czymś całkiem zrozumiałym i słusznym. Bo przecież tak wielu innych królów, doszedłszy do władzy i dosięgnąwszy dawnych swoich przeciwników, uznawało, iż nie licuje z piastowaną przez nich wielką godnością dochodzić sprawiedliwości względem swoich winowajców i w ten sposób zajmowana przez nich pozycja najwyższa dawała im okazję

$1101 \mathrm{Krl} 24,5$ - dokładnie mamy tu: „Oto chwila, o której Pan mówił ci, zapowiadając, że wyda w twoje ręce twojego wroga; że będziesz mógł uczynić z nim wszystko, co twoim oczom wyda się dobre". 
do przebaczenia. Jednakże niczego takiego tutaj stwierdzić nie można, a to dlatego, że Dawid oszczędził Saula, którego miał w rękach, nim przejął władzę, wówczas, kiedy nie objął jeszcze królowania - stąd nikt nie może powiedzieć, iż to potęga władzy, którą dzierżył, osłabiła jego gniew. Lecz nie zabił Dawid Saula, pomimo że był on świadomy, iż ten, skoro ocaleje, znów zwróci się ku swoim złym postępkom i że wystawi go na jeszcze większe niebezpieczeństwa. Nie porównujmy tedy Dawida z innymi królami. Wszak oni oszczędzają życie nieprzyjaciela, mając zagwarantowane bezpieczeństwo, nie bojąc się o nic. Dawid natomiast puścił wolno Saula, swojego wroga i ciemięzcę, i ocalił go, a nie zgładził, chociaż wiele powodów skłaniało go do dokonania tego morderstwa. Albowiem i nieobecność ludzi Saula, i nalegania jego własnych żołnierzy, i pamięć o wypadkach minionych, i obawa o to, co przyniesie przyszłość, i fakt, że zabiwszy króla, nie zostanie skazany za zabójstwo, co więcej, że w dalszym ciągu będzie mógł pozostawać kimś, kto przekracza Prawo - to wszystko, a zapewne jeszcze więcej, nakłaniało i przymuszało Dawida do tego, by przeszyć mieczem Saula. Ale żadna z tych racji nie zdołała złamać Dawida. Mocno trwał on bowiem przy swoim, zachowując nienaruszonym prawo filozofii. A żebyś nie mówił, że łatwo przyszło się Dawidowi pohamować i że była to niewrażliwość na to, co się z nim dzieje, nie zaś filozofia, zauważ, jak panował on nad sobą pomimo wzburzenia. Bo wzbierały w nim fale gniewu i targała jego sercem gwałtowna burza rozterek, ale ze strachu przed Bogiem powściągał on tę nawałę i poskramiał swe myśli, a można wnosić o tym na podstawie opisanych wydarzeń. Jako że mówi Pismo: „Wtedy Dawid podniósł się i tylko odciął po cichu frędzel płaszcza Saula"111. Czy nie widzisz, jak wielki sztorm gniewu tu się wzmaga? Lecz Dawid przetrzymał ów sztorm i nie dopuścił do tego, by okręt się roztrzaskał. Sternik bowiem onego okrętu, zbożny rozum, spostrzegłszy zawczasu, co się dzieje, opanował sytuację i nastał spokój. „Potem jednak - czytamy w Piśmie zaczęło serce wyrzucać Dawidowi"112; i ujarzmił on swój gniew, jak ujarzmia się szarpiącego się i narowistego konia.

6. Właśnie takie są dusze świętych: podnoszą się, zanim jeszcze runą i umieją się pohamować, nim popadną w grzech - ponieważ dusze te są przytomne i stale czuwają. Skoro odciął Dawid frędzel płaszcza Saula, to czyż trzeba było wiele, żeby zatopił swój miecz w ciele Saula? Był jednak na tyle silny, że nie posunął się dalej i z miejsca sprzeciwił się samemu

\footnotetext{
$111 \quad 1 \mathrm{Krl} 24,5$.

$1121 \mathrm{Krl} 24,6$.
} 
sobie. Powiada Pismo: „Zaczęło serce wyrzucać Dawidowi, że odciął frędzel jego płaszcza. Odezwał się więc Dawid do swoich ludzi: «Nie powinienem postępować wbrew Panu»" "113. To tak jakby mówił: „Oby Bóg był mi łaskawy, choćbym nawet sam tego chciał! I oby nigdy nie pozwolił mi Bóg uczynić tego, oby nie dopuścił, bym popadł w taki grzech!”. Skoro bowiem dogłębnie poznał tę wielką filozofię, która przekracza ludzką naturę i potrzebuje wsparcia z góry, i zdał sobie sprawę z tego, że był o krok od morderstwa, wówczas modlił się, aby Bóg zachował jego rękę w czystości. Czy znajdzie się dusza łagodniejsza od tej? A ponieważ w ludzkiej naturze okazał on anielski sposób życia, czyż powiemy o nim jeszcze „człowiek"? Nie, lecz nazwiemy go aniołem i nawet boskie prawa nie mogą nam tego zabronić. Pokaż mi bowiem kogoś innego, kto znalazłszy się na miejscu Dawida, natychmiast zwróciłby się do Boga z taką modlitwą na ustach, jaką ułożył Dawid? Co zaś mam na myśli, mówiąc: ,z taką modlitwą na ustach"? Otóż to: komu innemu łatwo przyszłoby powstrzymać się od przeklinania swojego prześladowcy? Przecież wielu jest takich, którzy ilekroć w swojej słabości nie są w stanie wyrządzić żadnej krzywdy swemu ciemnięzcy, zapędzają się tak daleko we wściekłości, że przyzywają samego Boga ku pomocy i błagają Go, aby pozwolił im zemścić się za wszystkie ścierpiane niesprawiedliwości. Dawid zaś zgoła odmiennie czyniąc, zanosi do Boga modlitwę, aby nie dozwolił mu On wziąć odwetu na Saulu za to, co go spotkało, mówiąc tak: „Nie mogę podnieść swej ręki na niego, bo przecież on jest namaszczony przez Pana!" 114 - a więc mówi o wrogu jako o synu Boga, jako o Jego prawowitym dziecku.

A nie tylko oszczędził Dawid Saula, lecz także bierze go w obronę. A spójrz, jak roztropnie i mądrze go broni! Kiedy bowiem rozpatrując jego życie, nie dopatrzył się w nim niczego dobrego i nie mógł powiedzieć, że Saul go nie krzywdził i że nie zaznał odeń niczego złego (bo gdyby tak powiedział, to obecni przy nim żołnierze, którzy na własnej skórze przekonali się o niegodziwości Saula, zaprzeczyliby temu), idzie na tułaczkę, starając się znaleźć dla Saula jakieś życzliwe usprawiedliwienie. A chociaż nie musiał iść na wygnanie, bo niczego złego nie zrobił ani też Saul nie nastawał bezpośrednio na jego życie, to jednak poszedł przez szacunek dla króla,

113 1Krl 24,6-7. Septuaginta podaje takie słowa Dawida: „Nie powinienem jednak wbrew Panu czynić takiej rzeczy mojemu panu, który jest namaszczony przez Pana. Nie mogę podnieść swej ręki na niego, bo przecież on jest pomazańcem Pana!’”.

$1141 \mathrm{Krl} 24,7$ : „Nie mogę podnieść swej ręki na niego, bo przecież on jest pomazańcem Pana!". 
powiedziawszy: „On jest namaszczony przez Pana”115. „Cóż mówisz? mógł rozważać Dawid w duchu - Że Saul jest ci obmierzły i to na wskroś obmierzły, że jest przepełniony złem i źle do ciebie nastawiony? Lecz przecież jest królem, jest władcą i to jemu zlecono, by nam przewodził!”. A nie powiedział Dawid o Saulu „król”. Lecz co powiedział? „On jest namaszczony przez Pana" ${ }^{116}$. Okazał tedy Saulowi cześć nie z racji na jego ziemską godność, ale z uwagi na dekret niebieski. „Czy śmiesz gardzić współniewolnikiem Boga? - mógł ciągnąć swe rozmyślanie Dawid - Uszanuj swego Pana! Będziesz opluwał Bożego wybrańca? Bój się Boga, który go wybrał!”. Bo przecież obawiamy się i lękamy tych rządców, którzy ustanowieni zostali przez królów, choćby i byli niegodziwcami, złodziejami, bandytami, krzywdzicielami i tym podobnymi, wcale nie dlatego, że nie widzimy ich podłości, ale dlatego, że zważamy na godność króla, który ich ustanowił - o ileż więc bardziej trzeba tak czynić w stosunku do wybrańców Bożych! „Póki co Bóg nie strącił przecież Saula z tronu - Dawid jakby rozważał - ani też nie uczynił go osobą prywatną". Dlatego i my nie odwracajmy panującego porządku ani nie walczmy z Bogiem, ale niech nasze czyny objawią ową apostolską naukę: „Kto więc przeciwstawia się władzy, przeciwstawia się porządkowi Bożemu. Ci zaś, którzy się przeciwstawili, ściągną na siebie wyrok potępienia"117. A Dawid nie tylko nazwał Saula namaszczonym, lecz także swoim panem. Określanie bowiem wroga tytułami wyrażającymi szacunek i cześć ${ }^{118}$ właściwe jest wyłącznie filozofii prawdziwej. A że jest to rzecz wielka, można się przekonać, patrząc, czego doświadczają inni. Toć większość ludzi zwykła nazywać swoich wrogów nie po prostu właściwymi im imionami, lecz wyzwiskami zawierającymi wiele oskarżeń: „łotr”, „szaleniec”, „obłąkaniec”, „głupek”, „łapówkarz”, dołączając do tych jeszcze inne, im podobne. Oto, w jaki sposób nazywają ludzie swoich wrogów. A że jest to prawda, pokażę ci na przykładzie $\mathrm{i}$ to nie jakimś wydumanym, ale zaczerpniętym z naszej historii, mianowi-

$1151 \mathrm{Krl} 24,7$.

$1161 \mathrm{Krl} 24,7$.

117 Rz 13,2. Fakt, iż Jan mówi tu w taki, a nie inny sposób o stosunku podwładnego do władcy i że przytacza taki właśnie, a nie inny urywek Apostoła, można by wykorzystać dla wzmocnienia uzasadnienia interpretacji tryptyku De Davide et Saule przedłożonej przez Hilla. Zob. Hill, Chrysostom 's Homilies on David and Saul, s. 5. Zob. także wstęp do niniejszego thumaczenia (3.1 Data i okoliczności powstania).

118 Rzeczownik $\tau$ ò ővo $\mu \alpha$ ma u Jana wiele znaczeń. Na ten temat zob. np. A. Eckmann, Tradycyjne znaczenie rzeczownika ,to onoma” u Jana Chryzostoma w ,Expositiones in Psalmos”, „Roczniki Humanistyczne” 25/3 (1977) s. 55-63. Tu chodzi po prostu o nazwę, imię, miano, tytuł. 
cie na przykładzie Saula. On to wszak z powodu wielkiej swej nienawiści do świętego Dawida nie mógł znieść wymawiania jego imienia, gdy więc szukał go podczas święta, zapytał: „Gdzie jest syn Jessego?”119. Spytał zaś o sprawiedliwego Dawida $\mathrm{w}$ ten sposób zarówno $\mathrm{z}$ tego powodu, że wstrętnym mu było jego imię, jak i z tej racji, że wspominając o jego ojcu, którego status był niski, spodziewał się umniejszyć Dawidową sławę, nie wiedząc, że to nie świetność przodków, ale cnota duszy czyni czyjeś imię słynnym i dostojnym. Lecz nie tak postępował nasz mąż błogosławiony. Nie nazywał bowiem Saula ani imieniem jego ojca, chociaż ten był nisko urodzonym wygnańcem, ani też zwyczajnie jego własnym imieniem, lecz zawsze mówił o nim i do niego, używając tytułu pełnego uszanowania i czci należnej władcy. Bo miał Dawid duszę całkowicie wolną od nienawiści.

Dlatego i ty, mój drogi, naśladuj Dawida i ucz się najpierw tego, żeby swojego wroga nazywać zawsze określeniami nie obraźliwymi, ale wyrażającymi szacunek. Bo jeśli usta będą pilnowały, by krzywdziciela określać z respektem i szacunkiem, wówczas i dusza usłyszawszy to, ucząc się od języka i przyswajając sobie wypowiadane przezeń słowa, zmieni swój stosunek do nieprzyjaciela. I słowa te będą najlepszym lekarstwem dla porywczego serca.

7. Opowiadam zaś teraz o tym wszystkim nie po to tylko, abyśmy pochwalili Dawida, lecz również po to, abyśmy go naśladowali ${ }^{120}$. Każdy niech więc sobie wymaluje tę historię w swoim sercu, myślami - niczym rękoma - wyrysowując kolejno ${ }^{121}$ głęboką jaskinię i leżącego w jej wnętrzu i snem

119 1Krl 20,27: „Co się stało, że ani wczoraj, ani dziś nie przyszedł do stołu syn Jessaja?”.

${ }^{120}$ Chcąc podkreślić, jaki jest cel jego przepowiadania - mianowicie skłonienie słuchaczy do naśladowania szlachetnej postawy Dawida - kończąc swoją mowę, wraca Złotousty do myśli wypowiedzianej na początku homilii (w jej części pierwszej) w słowach następujących: „Wypada wszak [...], żeby rozprawiając o łagodności i delikatności, i od siebie podać przykład owej pięknej filozofii, by nauczać jej przez słowa i przysposabiać do niej poprzez czyny. Ponieważ zaś bardzo potrzeba nam tej cnoty, wybrawszy jednego ze świętych i postawiwszy go przed waszymi oczyma, na jego przykładzie będziemy was usilnie zachęcać, żebyście - zagrzewani i przez nas, i przez siebie nawzajem - niczym jakiś wzorcowy obraz naśladowali cnotę tego sprawiedliwego".

121 Oto kolejny z elementów pedagogii naszego Antiocheńczyka. P. Szczur nazywa ten element ,wyryciem” tematu homilii w umysłach słuchaczy. Przytoczmy tu słowa przywołanego autora, w których pisze on o owym Chryzostomowym ,ryciu”: „Każdy człowiek posiada wyobraźnię i pamięć, w której może zachować wiele obrazów i słów. W nauczaniu doktryny chrześcijańskiej i zasad postępowania Chryzostom starał się wykorzystać tę dyspozycję. Podkreślał, że pierwszym celem ambitnego chrześcijanina powinno być zapamię- 
- jakoby kajdanami jakimiś - skutego Saula, wydanego w ręce człowieka, którego najdotkliwiej skrzywdził, i stojącego nad śpiącym Saulem Dawida, i obecnych przy nim żołnierzy nakłaniających go do morderstwa, i znów Dawida, tego błogosławionego filozofa, jak powściąga on gniew swój własny i swojej drużyny i jak staje w obronie tego, który tak wiele wobec nich zawinił. A nie tylko wszystko to nakreślmy sobie w myślach, ale także nieustannie rozmawiajmy o tym $\mathrm{z}$ innymi podczas zgromadzeń i wciąż powracajmy do tej opowieści w rozmowach z żoną i dziećmi ${ }^{122}$. Jeśli bowiem

tanie fragmentów Pisma Świętego i historii biblijnych, gdyż w ten sposób treści zapamiętane przez kogoś stawały się jego własnością, a ponadto były łatwo dostępne. Nawiązując do opowiadań o wielkich postaciach biblijnych, Chryzostom zachęcał do zapamiętywania tych historii: «kiedy przez słuchanie zapoznamy się z cnotami [ludzi] sprawiedliwych, i zachowamy je w głębiach naszego umysłu, to przez cały czas, jeśli zechcemy, możemy cieszyć się ich przyjemnym zapachem». Z tego względu celem wielu z retorycznych strategii Chryzostoma było «wyrycie» (np. przez wizualizację) tematu lub nawet dokładnych słów kazania w pamięci słuchaczy" (Szczur, Zasady pedagogii, s. 178-179).

${ }^{122}$ Warto odnotować w tym miejscu, że rodzinę uważał Złotousty za kościół domowy. Jak bowiem podaje S. Longosz (Rodzina kościotem domowym w myśli św. Jana Chryzostoma, „Vox Patrum” 53-54 (2009) s. 288), aż ponad dziesięć razy Chryzostom

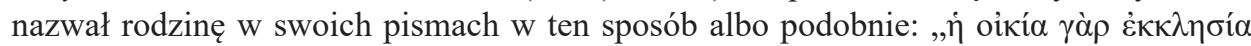

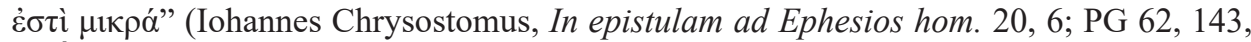
tt. Św. Jan Chryzostom, O malzeństwie. Homilia 20 na List do Efezjan, tt. M. Jurek, w: Św. Jan Chryzostom, O matżeństwie, wychowaniu dzieci i ascezie, tł. W. Kania - L. Małunowiczówna - K. Bielawski - M. Jurek - J. Sawicka, opr. J. Naumowicz, Biblioteka Ojców Kościoła 19, Kraków 2002, s. 47-69). Zob. na ten temat m.in. J. Höffner, „Euer Haus sei eine Kirche”. Der hl. Chrysostomus über das Apostolat der Eltern, „Die Kinderseelsorge” 5 (1938) s. 40-41; C. Scaglioni, Ideale coniugale e familiare in Giovanni Crisostomo, w: Etica sessuale e matrimonio nel cristianesimo delle origini, red. R. Cantalamessa, Milano 1976, s. 419-422 (punkt: La famiglia è una piccola chiesa); A. Bober, Rodzina Kościołem domowym wedlug św. Jana Chryzostoma, „Vox Patrum” 8-9 (1985) s. 193-200; H. Wójtowicz, Zadania rodziny chrześcijańskiej w nauczaniu św. Jana Chryzostoma, „Vox Patrum” 8-9 (1985) s. 201-214; W. Kania, Pierwsza rodzinna katecheza domowa w ujęciu św. Jana Chryzostoma, „Vox Patrum” 8-9 (1985) s. 215-222. Por. także: J. Szwed-Kostecka, Święty Jan Chryzostom o relacjach między kobieta a męzczyzna na przykladzie wybranych homilii, „Zeszyty Naukowe Towarzystwa Doktorantów Uniwersytetu Jagiellońskiego" 6 (2015) s. 105-126. Ów kościół domowy urzeczywistnia się - uczy Jan - kiedy w rodzinie gorliwie i bardzo uważnie czytane jest oraz medytowane i dyskutowane Słowo Boże, ono bowiem stanowi duchową strawę dla domowników odpowiadającą ich strawie materialnej. Dlatego Złotousty domaga się od słuchających go w kościele ojców, aby powróciwszy do swoich domów i rodzin, w czasie wspólnotowej lektury Biblii przekazywali swoim najbliższym, a także przyjaciołom wskazania i pouczenia biskupa: „Nie powinno się od razu po wyjściu z [naszego] zebrania rzucać się ku zaję- 
chcesz mówić o królu, oto masz króla - i jeśli chcesz mówić o żołnierzach albo o sprawach domowych czy politycznych, na wszystkie te tematy rzuci ci światło Pismo Święte. Historie biblijne są bowiem bardzo pożyteczne i niemożliwe jest, niemożliwe, żeby dusza obeznana $\mathrm{z}$ tymi historiami kiedykolwiek mogła zostać pokonana przez namiętność. Abyśmy zatem nie marnowali naszego czasu ani też bezmyślnie nie trwonili naszego życia na brednie niestosowne i niepotrzebne, zapoznawszy się z opowieściami o mężach szlachetnych, wciąż o nich rozprawiajmy. A gdyby ktoś spośród tutaj zebranych zechciał mówić czy to o widowiskach, czy o wyścigach konnych, czy o kwestiach, którymi nie przystoi się zajmować, odciągnąwszy go od onych tematów, zaznajom go z historią Dawida i Saula, abyśmy wszyscy, oczyściwszy dusze, ostrożnie zażywszy przyjemności, stając się życzliwymi i łagodnymi wobec wszystkich swoich prześladowców, odeszli stąd, nie mając żadnego wroga i byśmy posiedli dobra wieczne dzięki łasce i miłości do ludzi Pana naszego Jezusa Chrystusa, któremu chwała na wieki wieków. Amen.

\author{
Z języka greckiego przełożył, \\ wstępem i komentarzami opatrzył \\ ks. Łukasz Libowski ${ }^{123}$
}

ciom niestosownym dla usłyszanej nauki, lecz przyszedłszy do domu zaraz wziąć księgę do ręki, przywołać żonę i dzieci do uczestnictwa w przypominaniu tego, coś słyszał, a dopiero potem przystąpić do zajęć domowych" (Iohannes Chrysostomus, In Mattheum 5, 1, PG 57, 55, tł. Św. Jan Chryzostom, Homilie na Ewangelię wedtug św. Mateusza (część pierwsza: homilie 1-40), Źródła Myśli Teologicznej 18, tł. J. Krystyniacki, Kraków 2003, s. 68). Rodzicom z całą stanowczością poleca Jan, by w ogóle starali się zapoznać z treścią Pisma swoje dzieci; ,oto - dla przykładu - jego słowa: «Dziś, niestety, wasze dzieci śpiewają świeckie pieśni, a żadne z nich nie zna ani jednego psalmu; można przypuszczać, że się ich nawet wstydzą, czynią z nich żarty i wyśmiewają [...] Jeżeli wprowadzisz swe dziecko w psalmy od najwcześniej młodości, wprowadzisz je tym samym w rzeczy wyższe» (Iohannes Chrysostomus, Hom. 9,2, PG 62, 361)”. Cyt. za: A. Młotek, Pismo Święte jako źródło życia duchowego pierwszych chrześcijan, w: Żyjemy dla Pana. Księga pamiątkowa dedykowana S. Profesor Ewie Józefie Jezierskiej OSU w siedemdziesiąta rocznice urodzin, red. M. Rosik, Wrocław 2005, s. 456.

${ }_{123}$ Ks. Łukasz Libowski, kapłan diecezji opolskiej, mgr teologii (UO, 2013), lic. filozofii (KUL, 2018), lic. filologii klasycznej (KUL, 2020), obecnie doktorant w Katedrze Historii Filozofii Starożytnej i Średniowiecznej na Wydziale Filozofii Katolickiego Uniwersytetu Lubelskiego Jana Pawła II. Jako rozprawę doktorską przygotowuje edycję krytyczną pierwszych dwóch ksiąg komentarza Marsyliusza z Inghen do Metafizyki Arystotelesa; e-mail: lukasz.libowski@gmail.com; ORCID: 0000-0001-6175-0823. 